1.01

\title{
Dragan Potočnik*
}

\section{Knjižnice v Mariboru v obdobju od 1918 do $1941^{* *}$}

\section{IZVLEČEK}

Pokazatelj kulturnega dogajanja v Mariboru so gotovo tudi knjižnice. Knjižničarstvo je v mestu zaživelo po letu 1918. Iz predvojne znanstvene knjižnice Zgodovinskega društva za slovensko Štajersko se je leta 1921 izoblikovala splošna znanstvena Študijska knjižnica, ki je pod strokovnim vodstvom Janka Glazerja kmalu postala prva in največja slovenska znanstvena knjižnica na Štajerskem. Družbenopolitična in ideološka delitev je privedla do tega, da je bilo med obema vojnama javno knjižničarstvo $v$ Mariboru razdeljeno $v$ tri politične tabore: liberalnega z Ljudsko knjižnico, katoliškega s Prosvetno katoliško knjižnico in socialističnega s knjižnico Delavske zbornice. Pomembno narodnoprebudno in kulturno poslanstvo so opravljale tudi knjižnice Zveze kulturnih društev. Knjižnice pa so imeli tudi mariborski šolski zavodi in številna društva.

Ključne besede: Knjižnice v Mariboru, Študijska knjižnica, Ljudska knjižnica, Slovanska čitalnica, Prosvetna katoliška knjižnica, Knjižnica Delavske zbornice, Knjižnica Zveze kulturnih društev

\section{ABSTRACT}

\section{LIBRARIES IN MARIBOR BETWEEN 1918 AND 1941}

Libraries are one of the indicators of the cultural developments in Maribor. They spread around the city after 1918. In 1921, the pre-war scientific library of the Historical Society

* Dr., izr. prof., Univerza v Mariboru, Filozofska fakulteta, Oddelek za zgodovino, Koroška cesta 160, SI-2000 Maribor, Slovenija; dragan.potocnik@um.si

** Članek je nastal v okviru raziskovalnega programa Preteklost severovzhodne Slovenije med slovenskimi zgodovinskimi deželami in v interakciji z evropskim sosedstvom, št. P6-0138 (A), ki ga financira Javna agencija za raziskovalno dejavnost Republike Slovenije. 
for Slovenian Styria transformed into the general scientific Study Library. Under the expert leadership of Janko Glazer, it soon became the first and largest Slovenian scientific library in Styria. In the interwar period, the libraries in Maribor were - because of the socio-political and ideological splits - divided among three political camps: the liberals with the People's Library; the Catholics with the Educational Catholic Library; and the socialists with the Chamber of Labour Library. The libraries of the Association of Cultural Societies also played an essential role in national awakening and culture. The educational institutes and numerous societies in Maribor had their libraries as well.

Keywords: Maribor libraries, Study Library, People's Library, Slavic Reading Society, Educational Catholic Library, Chamber of Labour Library, Association of Cultural Societies Library

\section{Uvod}

Proces slovenskega narodnostnega osamosvajanja v Mariboru sega v leto 1859, ko je škofu Antonu Martinu Slomšku po dolgem spletu okoliščin in vztrajnih osebnih prizadevanj nazadnje le uspelo prestaviti sedež lavantinske škofije v Maribor. Maribor je tako postal pomembno cerkveno, narodno, politično in kulturno pa tudi gospodarsko središče štajerskih Slovencev.

Proces slovenskega narodnostnega osamosvajanja se je začel z ustanovitvijo Visoke bogoslovne šole in Slovanske čitalnice, nadaljeval pa se je ob časniku Slovenski narod, Narodni tiskarni, Slovenskem delavskem bralnem in pevskem društvu, Narodnem domu, Zgodovinskem društvu, Dramatičnem društvu in seveda ob pomoči vseh narodnozavednih posameznikov, ki so delovali še $\mathrm{v}$ drugih, tukaj neimenovanih društvih. Še posebej od začetka 20. stoletja pa je ta proces iz kulturnega boja s slovensko-slovanskim značajem vse bolj preraščal v politični boj za osamosvojitev od habsburške monarhije.

Maribor po letu 1848 ni doživel le pomembnih gospodarskih sprememb, ki jih je v marsičem pospešila železnica; po letu 1850 ni pridobil samo nove upravno-sodne organizacije, ampak je v tem času tudi javno kulturno napredoval, še posebej se je razmahnilo gledališko življenje, zelo pestro je bilo glasbeno življenje, delovala so mnoga društva in ne nazadnje so, še zlasti v 60 . letih 19. stoletja, v Mariboru nastajale tudi številne knjižnice (društvene, šolske, cerkvene). ${ }^{1}$

1 Podrobneje o literarnem ustvarjanju v Mariboru v obravnavanem obdobju gl. Dragan Potočnik, $\gg$ Literarna ustvarjalnost v Mariboru 1918-1941,« Studia Historica Slovenica 14, št. 2-3 (2014): 417-33. 


\section{Knjižnice v Mariboru pred prvo svetovno vojno}

Še posebej po letu 1869, ko je šolski zakon uzakonil šolarske in učiteljske knjižnice, se je število knjig v šolskih knjižnicah povečalo. Tako se je profesorska knjižnica mariborske gimnazije množila $\mathrm{z}$ darovi zasebnikov, visokih avstrijskih znanstvenih institucij in založnikov iz Avstrije, Ogrske in Nemčije. V dijaški knjižnici je bilo poleg nemške tudi nekaj slovenske literature.

Tudi mariborska višja realka je skrbno urejala svojo profesorsko in dijaško knjižnico, ki jo je množila s knjižnimi darovi znanstvenih in državnih institucij ter založnikov, veliko periodičnih publikacij pa je kupovala tudi sama. Višja realka kot izrazit nemški zavod ni zbirala in hranila slovenske literature. ${ }^{2}$

Vrednejši strokovno usmerjeni profesorski knjižnici sta imela še moško učiteljišče ter Sadjarska in vinarska šola, kjer je bilo tudi nekaj slovenske in hrvaške literature. Sicer pa so knjižnice na ljudskih šolah v mariborski mestni in sosednjih občinah imele izrazito nemški značaj, za kar je poskrbelo Nemško šolsko društvo (Deutscher Schulverein).

$\mathrm{Z}$ ustavno dobo so $\mathrm{v}$ mestu nastala številna društva. Nekatera med njimi so imela tudi lastne knjižnice $\mathrm{z}$ bralnicami, denimo Katholischer Gesellen-Verein, Theater und Kasino Verein, Turnverein, liberalno meščansko društvo Fortschritt in več delavskih izobraževalnih društev, Deutscher und Österreichischer Alpenverein. ${ }^{3}$

Precej dolgo se v Mariboru ni pojavila javna, ljudska knjižnica, namenjena vsem bralcem. Šele leta 1887 so v magdalenskem predmestju ustanovili Splošno bralno društvo (Allgemeiner Leseverein), ki je imelo svoj lokal ob Dravi, na Tržaški 6, v gostilni Johanna Holzknechta. Društvo je gojilo družabno življenje, imelo je svoj pevski zbor, prirejalo plesne vaje in družinske zabave, v svojem lokalu pa je imelo na voljo tudi nekaj dnevnikov in tednikov ter seveda knjižnico. Poglavitni namen društva je bil zagotoviti v narodnostnem boju nemščini »spet pravo veljavo «. V pravilih društva pa je bilo določeno, da naj se društveno premoženje v primeru razpada nameni ustanovitvi javne knjižnice v Mariboru. ${ }^{4}$

Do ustanovitve prve javne ljudske knjižnice je prišlo šele leta 1902. Mariborski podružnici društva Südmark, moška in ženska, sta knjižnico ustanovili kot pripomoček v narodnostnem boju za Maribor. Südmark je namreč ustanavljal knjižnice na jezikovno mešanih območjih $\mathrm{z}$ namenom, da bi nemške prebivalce teh območij trdneje navezovala na nemški narod. Tako je leta 1908 Südmark imel že 122 knjižnic. Društvo Südmark je v grajski slavnostni dvorani odprlo knjižnico, ki je sodila v vrsto tistih, ki jih je organizacija ustanavljala na narodnostno mešanih območjih, kjer je bila nemška stiska najhujša. $Z$ denarjem in knjižnimi darovi so jo podprli osrednji odbor v Gradcu,

2 Bruno Hartman, »Knjižnica mariborske realke (realne gimnazije) (1870-1941),« Časopis za zgodovino in narodopisje 56, št. 2 (1985): 140-45.

3 Bruno Hartman, »Knjižnice v Mariboru, « v: Maribor skozi stoletja. Razprave I, ur. Jože Curk, Bruno Hartman in Jože Koropec (Maribor: Obzorja, 1991), 698.

4 Franjo Baš, »Maribor v avstrijski ustavni dobi,« Časopis za zgodovino in narodopisje 38, št. 3 (1967): 232. 
podporniki iz vrst nemškega meščanstva in darovalci iz Avstrije in nemškega rajha. Knjižnica se je kmalu po ustanovitvi preselila iz gradu v lastne prostore na Koroški cesti 19 . Ob začetku poslovanja je razpolagala z okrog $2.000 \mathrm{knjigami.} \mathrm{Leta} 1908$ se je knjižnica preselila na Koroško cesto $2 .^{5}$

Prostori v Narodnem domu so omogočili tudi ureditev slovenske knjižnice. Čitalničarji so se lahko v novih prostorih temeljiteje lotili ureditve knjižnice, saj so nenehne selitve iz gostilne $\mathrm{v}$ gostilno in pogosto utesnjeni prostori to onemogočali. Leta 1905 so slovenski gimnazijski abiturienti sklenili predati svojo razredno knjižnico mariborski Slovanski čitalnici. S tem so dali pobudo za ustanovitev knjižnice (Ljudske knjižnice), ki bi bila namenjena širokemu občinstvu. Večina knjig čitalnice, dijaški darovi, gmotna podpora Posojilnice in politikov so omogočili, da je pod vodstvom Leopolda Poljanca Ljudska knjižnica hitro napredovala. Prvotno je bila nameščena v majhni sobi ob glavnem vhodu v Narodni dom. Ko se ji je priključila še strokovna sokolska knjižnica, ki sta jo vodila takratna odbornika čitalnice, profesorja Leopold Poljanec in Ljudevit Pivko, se je knjižnica že lahko pohvalila z uspehi. Na knjižnih policah je bilo $1.587 \mathrm{knjig}, 409$ vpisanih bralcev pa je prebralo $6.061 \mathrm{knjig}$. Število knjig in bralcev je raslo iz leta $v$ leto. ${ }^{6}$

Slovenska krščansko socialna zveza (SKSZ) za Štajersko ${ }^{7}$ si je kmalu po ustanovitvi uredila svojo osrednjo knjižnico s 4.370 knjigami, poleg njih pa je imela potujoče knjižne zbirke, s katerimi je zalagala narodnostno ogrožene kraje. Zveza se je z ustanavljanjem prosvetnih društev v župnijah, kjer so uredili tudi knjižnice, upirala raznarodovanju delavstva in viničarjev v mariborski okolici. Leta 1914 je zveza štela 167 društev na slovenskem Štajerskem. ${ }^{8}$

Delovanje omenjenih knjižnic je prekinila prva svetovna vojna. Narodni dom je zasedla vojska in Ljudska knjižnica je prenehala poslovati. Svoje delovanje je obnovila še med vojno, v začetku leta 1918.

Vojna je ohromila tudi delovanje Zgodovinskega društva. Kljub vojni pa je društvo izdajalo svoj časopis, ki je izšel, razen leta 1916, vsako vojno leto. Društvo je imelo tudi svojo knjižnico, ki je postavila osnove za slovensko domoznansko dokumentacijo. V začetku vojne je knjižnica še delovala. V letu 1915 je društvo nabralo preceǰ̌njo zbirko raznih knjig. Sklenili so, da jih bodo ponudili svojim članom. Društvena knjižnica je bila odprta vsak petek med peto in osmo uro zvečer, ko so lahko knjige in časopise brali v knjižničnih prostorih na Koroški cesti $10 \mathrm{v}$ prvem nadstropju. Društvo je izdajalo tudi Časopis za zgodovino in narodopisje (ČZN) in ga zamenjevalo za druge časopise.

5 Bruno Hartman, »'Südmarkini’ knjižnici v Mariboru, « Časopis za zgodovino in narodopisje 54, št. 1-2 (1983): 14648.

6 Bruno Hartman, »Slovanska čitalnica v Mariboru in njeni knjižnici, « Časopis za zgodovino in narodopisje 50, št. 1-2 (1979): 319, 320.

7 V devetdesetih letih pa so se tudi katoliški Slovenci združevali v nova združenja, od katerih se je zlasti uveljavila Slovenska krščansko socialna zveza (SKSZ), ki je bila ustanovljena na pobudo Janeza E. Kreka. Združevala je katoliška nepolitična društva. Še posebej se je posvetila prosvetnemu in kulturnemu delu. Hartman, »Knjižnice v Mariboru, « 698. 
Mariborčani so se zavedali pomena knjižnic in potrebe po veliki javni državni knjižnici, saj je z novo državo Maribor izgubil graško joanejsko knjižnico. Zato so pozivali Zgodovinsko društvo, da odstopi svojo knjižnico v ta namen. ${ }^{9}$

\section{Družbene razmere v Mariboru po letu 1918}

Družbenopolitične spremembe po prvi svetovni vojni so bistveno vplivale na kulturni razvoj Maribora. Obmejni Maribor je v novi državi Kraljevini SHS izgubil svoj prejšnji gospodarsko-prometni položaj. Spremenila se je narodnostna struktura prebivalstva.

Če upoštevamo predvojne razmere, je razumljivo, da je slovenizacija mesta po letu 1918 potekala postopno. Slovenska občinska uprava je izdala več zakonskih predpisov, s katerimi so bile odpravljene ponemčevalne organizacije. Izločila je ključne nemške institucije, kot sta bili Südmark in Schulverein. Kljub temu so mesto še vedno pretresala slovensko-nemška nasprotja. Nemci se z zlomom monarhije niso sprijaznili in niso sprejeli zgodovinskega dejstva nastanka jugoslovanske države. Kulturni razvoj Slovencev je omogočala šele slovenizacija šolstva. V začetku leta 1919 je s položaja župana sestopil zadnji župan avstrijske dobe, Johan Schmiderer (1902-1919). ${ }^{10}$ Aprila 1919 so šole zakonsko prevzeli slovenski učitelji.

Čeprav je večinsko prebivalstvo v mestu bilo slovensko, je imela nemška manjšina še naprej trden gospodarski položaj. Pred okupacijo leta 1941 je bilo 19 od 45 industrijskih podjetij v mestu v nemški lasti. V Mariboru je bilo v nemški lasti 41 odstotkov stanovanjskih in drugih poslopij. Posledice so se kazale na področju kulture. Nemci so s pomočjo kapitala razvijali svojo kulturo. Proti prevladi nemškega kapitala so si močno prizadevali mestna občina in razna društva, tako npr. Češki klub, ki je želel privabiti češke podjetnike in gospodarsko zmanjšati nemški vpliv v mestu.

$\mathrm{Na}$ kulturno dogajanje ${ }^{11} \mathrm{v}$ mestu so gotovo vplivale tudi politične razmere. Mariborsko meščanstvo je bilo med obema vojnama politično neenotno, razcepljeno na klerikalni in liberalni tabor. Delavstvo, ki je bilo ob prevratu še precej ponemčeno, se je odkrito zavzemalo za priključitev Maribora k Avstriji.

V Mariboru so začeli slovenske kulturne ustanove snovati že pred sklenitvijo Saintgermainske pogodbe. Poleti leta 1919 je začela delovati osrednja kulturna in umetniška institucija - Narodno gledališče. To je dalo močno spodbudo ljubiteljskim skupinam širšega mariborskega območja, ki so bile združene v katoliški Prosvetni zvezi, liberalni Zvezi kulturnih društev in v socialistični Svobodi ter kasnejši Vzajemnosti. Med temi so se uveljavili katoliški Ljudski oder, studenško sokolsko

9 Vlasta Stavbar, Kulturno dogajanje v Mariboru v letih 1914-1918 (Maribor: Založba Obzorja, 1998), 115-18.

10 Gregor Jenuš, »'Ljubi Bog, kako varovati, česar ni, saj vendar pri vseh koncih in krajih sili v Mariboru slovenski značaj na dan!': Johann Schmiderer - zadnji mariborski župan avstrijske dobe,« Studia Historica Slovenica 17, št. 3 (2017): 901.

11 O orisu širšega kulturnega dogajanja v obravnavanem obdobju gl. Dragan Potočnik, Kulturno dogajanje v Mariboru v letih 1918-1941 (Maribor: Založba Litera, 2003). 
gledališče, gledališče v Košakih, na Pobrežju, v Limbušu in Kamnici. Ljubiteljski odri so opravljali pomembno ljudskoprosvetno in narodnoprebudno delo. Predstave za delavce, organizirane v okviru Svobode in kasneje Vzajemnosti, so prispevale h kulturnemu ozaveščanju delavcev v Mariboru. V mestu je znotraj Kulturbunda delovalo tudi nemško gledališče. Delovali so še Dramski studio, Neodvisno gledališče, Toti teater, Gledališče mladega rodu idr. Številni odri kažejo na veliko priljubljenost gledališča med Mariborčani.

Priljubljena oblika zabave mariborskega prebivalstva je bil obisk kinopredstav. Grajski kino, Mestni kino (od leta 1925 kino Apolo), kino Union in Esplanade so navduševali obiskovalce $s$ sporedom, na katerem so prevladovale lahkotne komedije.

Med kulturno-znanstvenimi ustanovami sta bila pomembna Mestni muzej in Banovinski arhiv. Kulturno podobo Maribora je dopolnjevalo pestro glasbeno življenje. Po prevratu so nastale nove možnosti tudi za slovensko leposlovje in likovno dejavnost. Pravi pokazatelj slovenskega narodnega prebujanja in sploh kulturnega dogajanja pa so bile nedvomno mariborske knjižnice.

\section{Študijska knjižnica}

Temelji Študijske knjižnice so bili postavljeni že leta 1903, ko je bilo na ustanovnem občnem zboru Zgodovinskega društva v Mariboru sklenjeno, da je treba urediti društveno knjižnico z zgodovinsko literaturo. $V$ prvih letih obstoja se je njen knjižni fond večal predvsem $\mathrm{z}$ darovi in zamenjavami, zlasti za društveno glasilo Časopis $z a$ zgodovino in narodopisje.

Prevrat leta 1918 je društveni knjižnici prinesel pomembno pridobitev: pravico do dolžnostnih izvodov. Tako je poverjeništvo za notranje zadeve izdalo odlok in prisodilo Zgodovinskemu društvu pravico do obveznih izvodov vseh tiskovin, ki izidejo na ozemlju Narodne vlade v Ljubljani. Ta pravica je trajala do leta 1925, ko je bila omejena na tisk z ozemlja Mariborske oblasti. ${ }^{12}$

Odbor Zgodovinskega društva je pričakoval podržavljenje knjižnice, vendar mu kljub prošnjam, naj država prevzame knjižnico ali namesti vsaj knjižničarja, ni uspelo. Tako je knjižnica društva prihajala v vedno težji položaj. Dobila je obvezne izvode, ni pa imela uradnika, ki bi knjižnico urejal. Tudi njeni prostori so postajali pretesni, predvsem zaradi časopisja.

Akcija za ustanovitev javne študijske knjižnice v Mariboru je dobila nov zagon, ko je zanjo pokazala interes mestna občina. Tako je dr. Ivan Lah, takratni mariborski magistratni uradnik, 10. decembra 1919 Zgodovinskemu društvu poslal dopis, ki so mu sledili nadaljnji ukrepi. V dopisu je izrazil željo, da bi v Mariboru iz obstoječih knjižnic ustanovili enotno javno študijsko knjižnico. $V$ ta namen je mesto od zgodovinarja Antona Kaspreta kupilo knjižnico. Odboru Zgodovinskega društva so predlagali, da bi prepustil svojo knjižnico pod pogojem, da se ta preseli iz dotedanjih prostorov $\mathrm{v}$

12 »aredba z dne 16. decembra 1918, št. 194,« Uradni list XXIII, 17. 12. 1918. 
skupne prostore v deškem zavetišču. Lastninske pravice knjižnice bi ostale društvu. Mesto bi skrbelo za izpopolnitev knjižnice oziroma za ustvaritev take knjižnice, ki bo odgovarjala potrebam kulturnega napredovanja v Mariboru. Mesto se je tudi zavezalo, da bo ukrenilo vse potrebno, da preide knjižnica v državno upravo z državnim knjižničarjem. V tem primeru bi dobilo Zgodovinsko društvo od države primerno odkupnino.

O tej ideji je odbor Zgodovinskega društva razpravljal na seji 23. decembra 1919. Odborniki so se strinjali, da se v Mariboru ustanovi javna študijska knjižnica. Pripomnili pa so, da želijo natančno določitev pravnega subjekta, ki bo lastnik knjižnice, in da se Zgodovinsko društvo obravnava kot enakopraven dejavnik. Izrazili so zahtevoželjo, da se pri nabavljanju knjig upoštevajo posebni znanstveni, zgodovinski in narodopisni cilji Zgodovinskega društva. Zgodovinsko društvo je izrecno pripomnilo, da mora država javni knjižnici zagotoviti pomoč.

Toda zataknilo se je že pri prostorih. Mesto je bodoči javni študijski knjižnici namenilo prostore v deškem zavetišču, česar pa Zgodovinsko društvo ni sprejelo. Šele ko se je mestna občina obvezala, da omenjenih prostorov pred potekom desetih let ne bo odpovedala, je Zgodovinsko društvo predlog sprejelo. ${ }^{13}$ A mestna občina je prelomila dogovor $\mathrm{z}$ društvom o obljubljenih prostorih in tako se je vprašanje lokacije nove knjižnice nadaljevalo, dokler ni župan Viktor Grčar $(1921-1924){ }^{14}$ ponudil knjižnici prostorov v prvem nadstropju kazinskega poslopja na Slomškovem trgu 17. Konec septembra leta 1921 se je knjižnica preselila v ponujene prostore. V njih je delovala, razen med okupacijskim obdobjem, do leta $1951 .{ }^{15}$

S prostorskimi problemi se je Študijska knjižnica še posebej soočala v tridesetih letih, saj dotedanji prostori niso več zadoščali. ${ }^{16}$ Ideja o namestitvi v traktu mariborskega gradu ni zaživela. Leta 1940 so v prvem nadstropju mariborskega kazinskega poslopja, v katerem je imela prostore Študijska knjižnica, začeli prenovo. Knjižnica je za svoje knjižnične fonde dobila na razpolago še veliko kazinsko dvorano. Mestna občina je tako spet dokazala, da se je zavedala velikega kulturnega pomena te ustanove.

Ker knjižnica ni bila podržavljena, jo je prevzela mariborska mestna občina. S sklepom občinskega sveta, sprejetim 3. marca 1925, ko je županovanje že prevzel nekdanji vladni komisar ${ }^{17}$ dr. Josip Leskovar (1924-1928),, ${ }^{18}$ ji je s posebno pogodbo določila delovno področje in ji zagotovila gmotni obstoj. ${ }^{19}$ Pravno podlago za delovanje Študijske knjižnice je predstavljal statut, oblikovan januarja 1922 na posvetovanju, ki

13 Janko Glazer, Študijska knjižnica v Mariboru: zgodovina njenega nastanka (Maribor: Mariborska tiskarna, 1928), 12-19.

14 Podrobneje o njegovem županovanju gl. Dragan Potočnik, »Mariborski župan Viktor Grčar (1921-1924), « Studia Historica Slovenica 17, št. 3 (2017): 961-87.

15 Cene Kranjc, »Naše tiskarstvo v letih 1918-1938,« v: Spominski zbornik Slovenije: zbornik ob dvajsetletnici Kraljevine Jugoslavije, ur. Jože Lavrič, Josip Mal in France Stele (Ljubljana: Jubilej, 1939), 257.

16 »Mariborsko Študijsko knjižnico bodo preuredili,« Slovenec, 22. 10. 1938, 5.

17 Darko Friš, »Maribor po prevratu in vladni komisar dr. Josip Leskovar,« Studia Historica Slovenica 18, št. 1 (2018): 191-216.

18 Darko Friš, »Razmah in napredek Maribora v času županovanja dr. Josipa Leskovarja (1924-1928), « Acta Histriae 26, št. 1 (2018): 127-58.

19 Hartman, »Knjižnice v Mariboru, «699. 
ga je sklical župan Viktor Grčar. 3. marca 1925 je Mestni občinski svet na svoji seji sprejel nov statut, ki je določal, da se knjižnica imenuje Študijska knjižnica v Mariboru. Po statutu je bila lastnica knjižnice mestna občina, ki je dajala prostore, vzdrževala osebje in $\mathrm{z}$ denarno podporo omogočala njen obstoj in razvoj. Upravljal jo je poseben kuratorij, sestavljen iz sedmih članov: štiri je delegirala mestna občina, dva Zgodovinsko društvo in enega Muzejsko društvo. Knjige, ki sta jih prispevali ali bi jih v prihodnje, so ostale njuna last. S konstituiranjem kuratorija kot zakonodajnega organa in namestitvijo knjižničarja je bila uprava knjižnice jasneje definirana. ${ }^{20}$

$\mathrm{V}$ novih prostorih, v prvem nadstropju kazinskega poslopja, je mestna občina izročila Študijski knjižnici tudi knjige, ki so bile v čitalnici prejšnjega lastnika društva Theater und Kasino Verein. Leta 1922 sta se knjižnici priključila del magistratne knjižnice, ki je vseboval večinoma starejša dela upravno-pravnega značaja, in knjižnica bivše mariborske sekcije Nemškega in avstrijskega planinskega društva. Že junija leta 1920 pa je ljubljanska vlada prepustila Zgodovinskemu društvu knjige bivše Südmark Volksbucherei. Na pobudo Zgodovinskega društva se je s Študijsko knjižnico združila tudi knjižnica Muzejskega društva. Leta 1924 je dobila še knjižnico Lavantinskega škofijskega muzeja. Pobudo, da bi se Študijska knjižnica združila tudi z Ljudsko knjižnico v Mariboru, je Slovanska čitalnica 28. marca 1922 zavrnila. $^{21}$

Za obstoj in razvoj Študijske knjižnice sta bila tako dana oba nujna pogoja, se pravi prostori in knjige. Manjkal je še knjižničar, ki bi vse združene zbirke enotno uredil in upravljal. Že decembra 1919 je Zgodovinsko društvo v svoji prošnji za podporo, vloženi pri Poverjeništvu za uk in bogočastje v Ljubljani, prosilo, naj v Mariboru čim prej ustanovijo javno znanstveno knjižnico, arhiv in muzej, naj se dobijo zanje primerni prostori in nastavijo državni uslužbenci. Dobili so le izredno podporo v znesku 1.500 din in podporo v obliki priznanja dolžnostnih izvodov ter začasne zaposlitve knjižničarja Ivana Favaia. Šele ko je vzdrževanje knjižničarja prevzela mestna občina, so se razmere izboljšale. Tako je bil na seji mestnega sveta 14. januarja 1922 Franc Botolen imenovan za začasnega knjižničnega slugo in hišnika v kazinskem poslopju. Na seji mestnega občinskega sveta 9. marca 1923 pa so namestili še knjižničarja. To je postal podpolkovnik Davorin Žunkovič. Da bi se urejevanje knjižnice pospešilo in da bi se uvedla dnevna izposoja, je mestni občinski svet julija 1923 knjižnici dodelil še kneginjo Elizabeto Obolensko. ${ }^{22}$ Študijska knjižnica je zdaj mogla polno zaživeti. Toda s poslovanjem knjižnice njeni ustanovitelji niso bili zadovoljni. Knjižničar Davorin Žunkovič namreč ni imel ustreznih kvalifikacij niti potrebnega odnosa do knjig. ${ }^{23}$ Ker sta bila Davorin Žunkovič in Elizabeta Obolenska na delo sprejeta le začasno, so na predlog

20 PAM, MOM, š. 300, št. spisa 5982, Kuratorij Študijske knjižnice v Mariboru.

21 Janko Glazer, »Študijska knjižnica v Mariboru. Zgodovina njenega nastanka, « v: Razprave, članki in ocene, ur. Viktor Vrbnjak (Maribor: Obzorja, 1993), 736-41.

22 Bruno Hartman, »Dvoje nenavadnih mariborskih knjižničarjev,« Časopis za zgodovino in narodopisje 64, št. 2 (1993): 229-40.

23 »Nered v Študijski knjižnici,« Jutro, 18. 2. 1926, 6. 
kuratorija 1. oktobra 1926 za stalnega knjižničarja imenovali Janka Glazerja. ${ }^{24}$ Ta je leta 1931 postal tudi njen ravnatelj. Pod njegovim vodstvom je knjižnica kmalu postala reprezentativna kulturna ustanova $\mathrm{v}$ mestu in se razvila $\mathrm{v}$ eno najboljših $\mathrm{v}$ Sloveniji.

Do konca leta 1924 so poleg namestitve knjižničarja na novo opremili tudi knjižnični prostor. Po preureditvi knjižnice so knjižnico in čitalnico odprli za občinstvo. Bralci so lahko izbirali knjige na dveh oddelkih: znanstvenem in leposlovnem. Vstop $\mathrm{v}$ čitalnico je bil prost. Ob ponedeljkih in petkih, ko so bila predavanja na Ljudski univerzi, ki je gostovala v čitalniških prostorih, so mize zložili ob vhod. Na levi strani ob steklenih vratih v glavno dvorano so bile police $\mathrm{z}$ revijami, ob steni na drugi strani pa je bilo nekaj časnikov na kavarniških držajih. ${ }^{25} \mathrm{O}$ književnih novostih je bralce obveščal Časopis za zgodovino in narodopisje.

Graf 1: Primerjava stanja Študijske knjižnice v letih 1923 in 1938

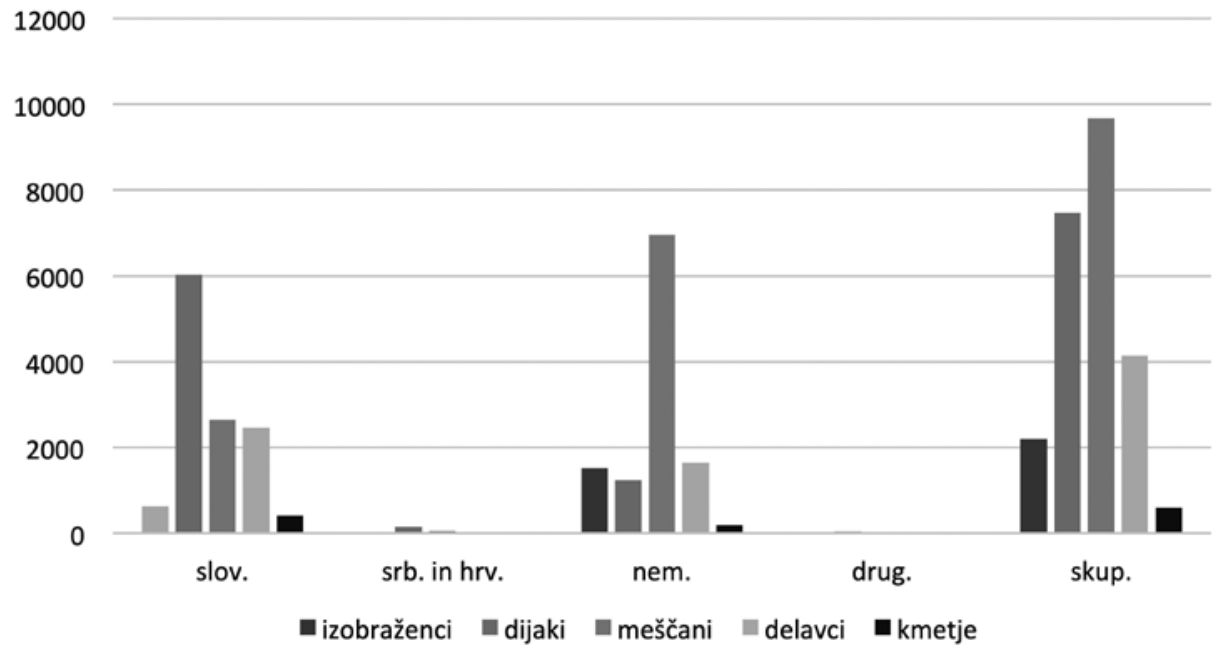

Podatki o številu knjig, obisku in izposojenih knjigah kažejo na to, da je knjižnica zelo napredovala. V letu 1940 je Študijska knjižnica »štela« okoli 43.000 izvodov. Med temi je bila približno ena tretjina slovenskih, ostali so bili slovanski, nemški, francoski, angleški itd. V letu 1924 je dnevno prihajalo v knjižnico od 15 do 20 oseb. Leta 1932 se je dnevni obisk knjižnice podvojil. Več kot polovica izposojenih knjig v Študijski knjižnici je bila slovenskih, namenjene pa so bile predvsem znanstvenemu delu. Največ izposojevalcev je prihajalo iz vrst dijakov in študentov, ki so segali po strokovni literaturi v slovenščini; nemščino so mladi v drugi polovici tridesetih letih slabše obvladovali, saj so to že bile generacije, ki so se šolale samo v slovenščini. ${ }^{26}$

24 Janko Glazer se je rodil 21. 3. $1893 \mathrm{v}$ Rušah in umrl 2. 2. $1975 \mathrm{v}$ Rušah. Zapisal se je v anale slovenske slovstvene in kulturne zgodovine na različnih področjih. Bil je pesnik, literarni in kulturni zgodovinar, kritik, prevajalec, urednik, bibliotekar in dolgoletni ravnatelj Študijske knjižnice v Mariboru (danes Univerzitetna knjižnica Maribor). 
Graf 2: Izposoja knjig leta 1938

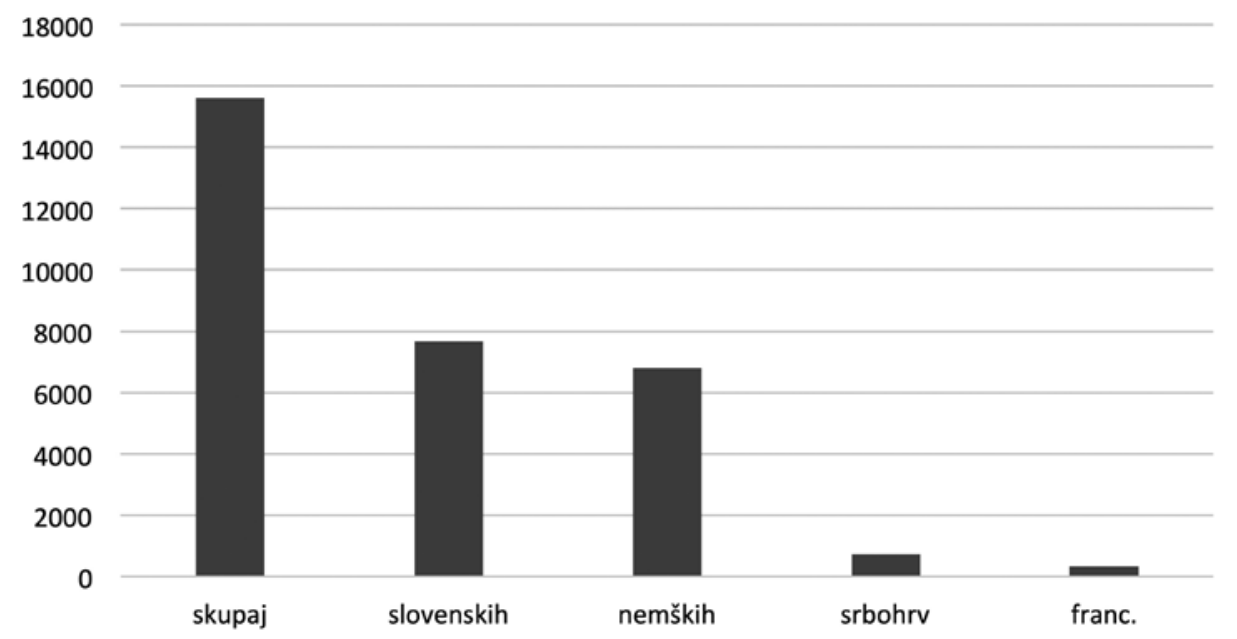

\section{Ljudska knjižnica in Slovanska čitalnica}

V prvih letih po prevratu je bila Slovanska čitalnica še vedno pomemben center družabnega življenja v mestu. V novih razmerah pa se je krog njenega delovanja sčasoma vse bolj ožil. Glavna skrb je postala Ljudska knjižnica in čitalnica.

Potem ko so Slovanski čitalnici 1. januarja 1919 vrnili prejšnje prostore $\mathrm{v}$ Narodnem domu, ki so bili do tedaj zasedeni z vojaštvom, je spet organizirala delo. Njeni pogoji za delo so bili neustrezni. Tako denimo knjižnica zaradi neogrevane sobe pozimi leta 1920, v času, ko je s položaja vladnega komisarja za Maribor sestopil dr. Leskovar, ${ }^{27}$ ni bila niti odprta. ${ }^{28}$

Leta 1921, ko je vladnega komisarja za Maribor, dr. Leskovarja, za nekaj mesecev zamenjal Ivan Polanec (1921), ${ }^{29}$ je minevalo 60 let od ustanovitve Slovanske čitalnice. Društvo je razen narodne slovesnosti želelo to obletnico kulturnega delovanja proslaviti tudi s tem, da odpre mariborskemu in okoliškemu prebivalstvu Ljudsko knjižnico. Za uresničitev tega je bilo treba nakupiti nove knjige, nabaviti omare in drugo potrebno opremo za knjižnico ter nastaviti stalnega knjižničarja. Za realizacijo zastavljenih ciljev bi morali zbrati veliko denarja, zato so čitalničarji iskali različne vire, ki bi jim naklonili denarno podporo. Veliko dela so opravili kar sami, nasproti pa sta jim z denarno pomočjo prišla Posojilnica in magistrat mesta Maribor.

Prenovo so začeli tako, da so naprosili mariborske lesne trgovce za deske, iz katerih so napravili prepotrebne omare za nove knjige. Nato se je društvena knjižnica, ki je bila

27 Friš, $\gg$ Maribor po prevratu $\ll, 215$.

28 PAM, fond Slovanska čitalnica Maribor, š. 2. Zapisnik odborove seje 14. januarja 1921.

29 Dragan Potočnik, »Vladni komisar Ivan Poljanec (1921), « Studia Historica Slovenica 17, št. 3 (2017): 949. 
na razpolago le članom, združila z Ljudsko knjižnico. Kizboljšanju stanja knjižnice so po svojih močeh pripomogli tudi čitalničarji, ki so pri prenovi pomagali $\mathrm{z}$ delom in finančno podporo. Odpovedali so se društvenemu biljardu, da so lahko z izkupičkom nakupili opremo za knjižnico. Za denarne prispevke so prosili tudi javnost. ${ }^{30}$

Istega leta se je knjižnica preselila v visoko pritličje, $v$ prostore, iz katerih se je izselila Zveza jugoslovanskih železničarjev. Jeseni je nove prostore že krasilo šest velikih omar. Knjige so bile na novo urejene in več sto jih je dobilo trde platnice. Njihovo število se je pomnožilo na štiri tisoč. Knjižnica je bila odprta dvakrat tedensko. Knjižničarju dr. Avgustu Reismanu sta bila v pomoč še dva knjižničarja in dijaki. Na večer so povprečno izposodili do $200 \mathrm{knjig}$. Odprti so bili različni oddelki - slovenski, srbohrvaški, češki, nemški, italijanski, francoski, angleški in ruski. Ustanovili so tudi mladinski oddelek. Sistematično delo v knjižnici, ki ga je uvedlo vodstvo leta 1921, je pripomoglo $\mathrm{k}$ temu, da je knjižnica postajala vse pomembnejša.

Tudi v naslednjem letu so $\mathrm{z}$ vsemi sredstvi izpopolnjevali Ljudsko knjižnico. Slovenski oddelek so obogatili z nekaj sto starimi knjigami. Kupovali so vsaj po en izvod vsake novoizdane slovenske knjige. Tudi srbohrvaški oddelek je bil bogato založen in ga je uporabljala predvsem srednješolska mladina. Sproti so kupovali najpomembnejše prevode svetovnih pisateljev. Dobro založena je bila tudi čitalnica, kjer so lahko segli po časopisih Slovenski narod, Slovenec, Tabor, Marburger Zeitung, Nova doba, Jutro, Riječi, Straža, Dom in svet, Njiva in Ljubljanski zvon.

Ker je bilo povpraševanje mladine vse večje, so uvedli posebno izposojo za mladinski oddelek. Zanj se je zanimalo tudi sokolsko društvo, kar je privedlo do tega, da so za mlade sokole uvedli posebne sokolske izkaznice. Število izposojevalcev je naraščalo, še posebej v zimskem času, zato so organizirali tudi nabiralne akcije, s katerimi so želeli dobiti sredstva za nakup knjig. Število knjig v knjižnici namreč ni več zadoščalo velikim potrebam mesta.

V tem letu je bilo aktualno tudi vprašanje združitve Ljudske knjižnice s Študijsko knjižnico. Zgodovinsko društvo se je obrnilo na čitalnico s pozivom, da odstopi svojo knjižnico v skupno upravo. Odbor se je na svojih sejah odločil, da se Študijski knjižnici ne pridružijo, ker ne zaupajo obljubljenim podporam vlade in občine. Ugotovili so še, da se razlikuje njun osnovni namen. Knjige Ljudske knjižnice naj bi bile namenjene navadnemu prebivalstvu, Študijska knjižnica pa znanstvenemu delu. ${ }^{31}$

Vse bolj je postajalo očitno, da Slovanska čitalnica ni bila več žarišče narodnega in kulturnega življenja v mestu. $\mathrm{Na}$ 63. rednem občnem zboru 26. januarja 1924 so zato sklenili, da je treba pridobiti večje število članov iz različnih krogov, ker se bo sicer njen delokrog omejil le na Ljudsko knjižnico. Da se to ne bi zgodilo, so sklenili, da bodo navezali stike s Srbi in Hrvati, živečimi v Mariboru. Že kmalu so pripravili tri lepo obiskane večere: 5. aprila je bila proslava ob stoletnici pesnika Branka Radičevića, 28. junija sta bila predavanje polkovnika Stojana Nikolića o kosovski bitki in poslovilni večer polkovnika Mihelinovića. S tem sodelovanjem je Slovanska čitalnica nadaljevala

30 »Dnevna kronika, « Tabor, 13. 2. 1921, št. 35, 2.

31 Hartman, »Slovanska čitalnica v Mariboru, « 328-32. 
tudi naslednja leta. Tako so pripravili tudi dve odhodnici; bivšemu odborniku polkovniku Stojanu Nikoliću in polkovniku Kovačeviću. ${ }^{32} \mathrm{Da}$ bi svojo dejavnost čim bolj razširili, je Slovanska čitalnica ustanovila tudi koncertno agenturo, ki pa ni izpolnila pričakovanj odbornikov. Med prireditvami je bil odmeven Kejžarjev ${ }^{33}$ večer, ki je potekal po zaključku občnega zbora društva 2. februarja 1926. Pripravili pa so tudi nekaj predavanj, tako je dr. Avgust Reisman predaval o ustroju in pomenu Ljudske knjižnice.

V naslednjih letih delovanja se je delovanje Slovanske čitalnice vse bolj omejevalo na kulturno poslanstvo, ki ga je opravljala Ljudska knjižnica. Zaradi finančnih težav je bil v čitalnici na voljo le skromen izbor časopisja.

Leta 1926 se je stanje Slovanske čitalnice še poslabšalo. Kot Damoklejev meč je nad čitalnico visela odpoved dotedanjih prostorov. Posojilnica kot lastnica Narodnega doma je sklenila stavbo preurediti, zato naj bi se Slovanska čitalnica izselila iz svojih dveh sob v prvem nadstropju v veliko sobo v pritličju. Odbor se je soglasno odločil, da odpovedi ne sprejme, saj so čitalnični odborniki svojčas sami sprožili idejo o zgradbi Narodnega doma, v katerem so bili izrecno določeni prostori za Slovansko čitalnico. ${ }^{34}$ A ugovori niso pomagali. Posojilnica je knjižnici odpovedala zgornje prostore in z 31. januarjem 1927 so se morali preseliti v pritličje. $V$ novih prostorih so začeli poslovati sredi tega leta. Za opremo novih prostorov jim je Posojilnica namenila tudi finančno

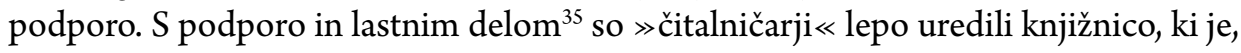
kot je zapisal poročevalec v Mariborskem večerniku Jutra, dajala »velemestni vtis «. ${ }^{36}$

Po ureditvi novih prostorov je poslovni promet na splošno zadovoljstvo tako narasel, da so vsi dijaki komaj zmogli delo. V tem letu je v čitalnico pristopilo mnogo novih članov, zlasti veliko iz delavskih krogov. Bralci so največ posegali po nemškem čtivu, saj je bila izposojena kar 3.101 nemška knjiga (slovenskih so izposodili 2.106, čeških 241, srbskih in hrvaških 240, knjig v drugih jezikih 87). Še naprej so nabavljali novosti (542 novih knjig). Knjige so nakupovali tudi antikvarično. Uspehe Ljudske knjižnice so priznavali tudi v nasprotnem političnem taboru. Tako je katoliški Slovenec 9. januarja 1927 zapisal: »Ljudska knjižnica $v$ Mariboru je še edina napredna kulturna ustanova, ki uspeva, pa ne po zaslugi demokratov, ampak vsled podpore v javnosti. Vse druge kulturne institucije, ki so $v$ demokratskih rokah spe spanje pravičnega. ${ }^{37}$

Po časopisnem članku, objavljenem v Taboru 1. januarja 1927, lahko sklepamo, da so lahko bili bralci z izborom knjig zadovoljni, in to najširši sloji pa tudi literarni izbirčneži. ${ }^{38}$ Med bralci so bili zastopani vsi sloji, največ je bilo državnih nameščencev in dijakov. Sledili so posebni nameščenci, obrtni pomočniki, zasebniki, obrtniški

32 Avgust Reisman, »Ljudska knjižnica v Mariboru v letu 1925,« Jutro, 5. 2. 1926, 6.

33 Predsednik Slovanske čitalnice Ivan Kejžar, višji železniški preglednik, je deloval v številnih društvih, še posebej pred prvo svetovno vojno, ko se je v Mariboru bíl narodni boj. Zlasti je pomembno njegovo delo na področju delavskega gibanja, še posebno železničarstva. - Bruno Hartman, Zgodovina slovenskega dramskega gledališ̌̌a v Mariboru do druge svetovne vojne (Maribor: Založba Obzorja, 1996), 48.

34 UKM, Rokopisna zbirka, Slovanska čitalnica, Maribor, Ms 201/IV, 6.

35 Nove prostore je uredil knjižničar Lojze Doležal skupaj s dijaki.

36 » obnovljeni ljudski knjižnici, « Mariborski večernik Jutra, 25. 7. 1927, 2.

$37 \gg$ Maribor, « Slovenec, 9. 1. 1927, 5.

38 Dr. Avg. Reisman, »Ljudska knjižnica v Mariboru, « Tabor, 1. 1. 1927, 3. 
vajenci, trgovci, obrtniki in trgovski pomočniki. Poleg teh so vodili še poseben seznam za sokolski naraščaj.

Redni obiskovalci knjižnice so bili tudi Nemci. V bogato založeno knjižnico so želeli pritegniti okoličane, zato so se dogovorili z okoliškim učiteljskim društvom, da bodo ob zborovanju učiteljskega društva uvedli posebno izposojevalno uro. S svojim delovanjem je Ljudska knjižnica posegla tudi izven Narodnega doma. Pomagala je pri ureditvi knjižnice $v$ mariborski jetnišnici in kaznilnici. Na ta način je $v$ ta zavod prodrla s svojimi knjigami.

Najboljši dokaz za to, kakšen ugled je uživala Ljudska knjižnica, je dejstvo, da ji je mestni magistrat naklonil 15.000 din podpore; pa tudi razne institucije, zasebniki in drugi so se vse bolj zavedali pomena Ljudske knjižnice, zlasti Posojilnica.

Konec leta 1924 je imelo društvo 238 članov, knjižnica pa je imela že več kot 7.000 knjig. Knjižnica je v tem letu dobila dragocen knjižni dar (gre za volilo po zapuščini) dr. Pavla Turnerja, dolgoletnega čitalničarja in predsednika Zgodovinskega društva. ${ }^{39}$

Naslednje leto je knjižnica imela 9.256 knjig. Izposodili so okrog 30.000 knjig. Iz članka v Jutru, objavljenega 5. februarja 1926, izvemo, da so obiskovalci knjižnice najraje segali po klasikih in Cankarju, v modi je bil tudi Tarzan. Tako je bilo vseh 58 knjig o Tarzanu, kolikor jih je imela knjižnica, vedno izposojenih. Prav tako tudi 70 knjig Karla Maya. V srbohrvaščini so segali po Avgustu Šenoi in francoskih prevodih, v češkem po Aloisu Jirasku in Karlu Čapku, v nemškem pa so prevladovali Hanns Heinz Ewers, Karl May in prevodi iz ruščine. ${ }^{40}$

Istega leta so zaradi izostale podpore in majhnega dohodka iz nabiralne akcije morali nekoliko povišati izposojnino, zato je obisk padel. Povišanje pa je bilo nujno, če so hoteli redno nabavljati vse novosti.

Proti koncu dvajsetih let je mogoče ugotoviti, da je začel obisk v knjižnici upadati. Vzrokov je bilo več. Vse večja je bila konkurenca dnevnega časopisja in revij, močno konkurenco sta predstavljali tudi knjižnici pri Prosvetni zvezi in Delavski zbornici. Dr. Avgust Reisman je na 68. občnem zboru, ki je potekal 2. julija 1929, med razlogi za manjši obisk navedel tudi, da mladi za knjige nimajo več toliko časa kot včasih. Več časa raje posvetijo športu. Sklenili so, da se bo knjižnica prilagajala razmeram tako, da bo kupovala tudi knjige $\mathrm{z}$ manjšo literarno vrednostjo, toda zanimive in napete. ${ }^{41}$

Vse bolj se je čutila gospodarska kriza, ki je Maribor v polnem obsegu dosegla $\mathrm{v}$ času županovanja dr. Alojzija Juvana (1928-1931 in 1935-1941). ${ }^{42}$ Vzdrževalni stroški so bili veliki, zato je bilo vse manj denarja za nabavo knjig. Podpore so skoraj ugasnile. Posledica tega je bila, da so se morali odpovedati kulturni manifestaciji, $\mathrm{s}$ katero so želeli obeležiti 70-letnico delovanja Slovanske čitalnice. A kljub težkemu gospodarskemu položaju je izposoja naraščala. V vsem medvojnem obdobju je leta

39 UKM, Rokopisna zbirka, Slovanska čitalnica Maribor Ms 201. Zapisnik 71. občnega zbora, 24. 6. 1932.

40 Avgust Reisman, »Ljudska knjižnica v Mariboru v letu 1925,« Jutro, 5. 2. 1926, 6.

41 UKM, Rokopisna zbirka, Slovanska čitalnica, Maribor, Ms 201/IV, 6.

42 David Hazemali, Mateja Matjašič Friš, Ana Šela in Majda Schmidt, »Med priložnostmi in pomanjkanjem: Maribor v času prvega županskega mandata dr. Alojzija Juvana, 1928-1931,« Acta Histriae 26, št. 1 (2018): 160. 
1931, ko je Juvana zamenjal dotedanji podžupan dr. Franjo Lipold (1931-1935), ${ }^{43}$ dosegla vrhunec. ${ }^{44}$

V začetku leta 1932 je Slovanska čitalnica v čakalnici Ljudske knjižnice odprla še Čitalnico za revije. Tako je izpopolnila vrzel, ki je nastala z opustitvijo časopisov pri Slovanski čitalnici. Leta 1927 je namreč morala opustiti čitalnico, ker je bila naročnina za časopisje previsoka. Med revijami so bili bralcem na voljo Ljubljanski zvon, Dom in svet, Modra ptica, hrvaška revija založbe Binoza - 15 dana, od nemških pa Die literatische Welt, Bucherkreis, Socialistische Bildung in druge. Za razvedrilo so bile v čakalnici tudi zagrebške Koprive.

Delovanje Slovanske čitalnice se je po letu 1932, tako kot prej, omejilo na vzdrževanje Ljudske knjižnice, ki je kljub težkemu gospodarskemu položaju dobro uspevala. Še naprej je opravljala kulturno poslanstvo v Mariboru. Vse bolj obiskana je bila tudi čitalnica revij. Leto kasneje se je položaj Ljudske knjižnice poslabšal, saj je to leto izostala tudi običajna podpora Posojilnice, tako da je morala Slovanska čitalnica vzdrževati Ljudsko knjižnico brez javne podpore. $\mathrm{V}$ tem letu je bilo slišati očitke, da Ljudska knjižnica naroča preveč nemških knjig in nabavlja knjige z marksistično vsebino. $\mathrm{Na}$ očitke, zakaj naroča toliko nemških knjig, je predsednik Ljudske knjižnice odgovarjal, da so nemške knjige prisiljeni naročati in izposojati, saj bi sicer izgubili mnogo bralcev. Ti bi šli potem po knjige $\mathrm{v}$ knjižnico Kulturbunda. ${ }^{45} \mathrm{~V}$ tem letu so nakupili približno 5 odstotkov nemških izvirnih del, 95 odstotkov nakupljenih knjig pa so predstavljali prevodi iz ruščine, francoščine in angleščine.

V Slovanski čitalnici so leta 1936 slavili tudi dva jubileja: 75-letnico čitalnice in 30-letnico Ljudske knjižnice. Zaradi prezaposlenosti s kulturnim delom v delavskih organizacijah je odstopil predsednik Ljudske knjižnice dr. Avgust Reisman. Izvolili so novega predsednika Nika Vrabla. Slovanska čitalnica je obstajala do aprila 1941, ko jo je odpravil ukrep okupacijske oblasti.

Primerjava izposoje literature v nemškem in slovenskem jeziku kaže, da je bila izposoja nemške literature ves čas višja. Razmerje med njima se je proti letu 1939 začelo izravnavati. Izposoja nemških in slovenskih knjig pa je proti koncu desetletja upadala. Število novih knjig je bilo vse manjše (leta 1935 še 391, leta 1939 le še 127). Tudi obisk je vse bolj padal (leta 19357.812 obiskovalcev, leta 1939 le še 2.874). Izposoja se je v tem obdobju več kot prepolovila (leta 1935 19.412, leta 1939 le še 8.228). ${ }^{46}$

43 Podrobneje o županovanju dr. Lipolda gl. Nina Gostenčnik, »Dr. Franjo Lipold, mariborski mestni načelnik v letih od 1931 do 1935,« Studia Historica Slovenica 17, št. 3 (2017): 989-1028. Hazemali et al., »Med priložnostmi in pomanjkanjem, $\ll 164$.

44 A. J., »Glavna skupščina Sokolske župe Maribor, « Mariborski večernik Jutra, 2. 3. 1931, 3.

45 UKM, Rokopisna zbirka, Slovanska čitalnica, Maribor, Ms 201/IV,6. Zapisnik 72. občnega zbora, 24. 4. 1933.

46 Podatki iz letnih poročil: PAM, MOM, š. 424, št. spisa 7810, Prosvetna knjižnica v Mariboru s podatki o delu v letu 1935. PAM, MOM, š. 442, št. spisa 9306, Poročilo Prosvetne knjižnice v Mariboru za leto 1936. PAM, MOM, š. 456, št. spisa 9102, Poročilo za leto 1937. 
Graf 3: Izposoja slovenskih in nemških knjig (zelena krivulja predstavlja izposojo nemških knjig, rdeča pa slovenskih)

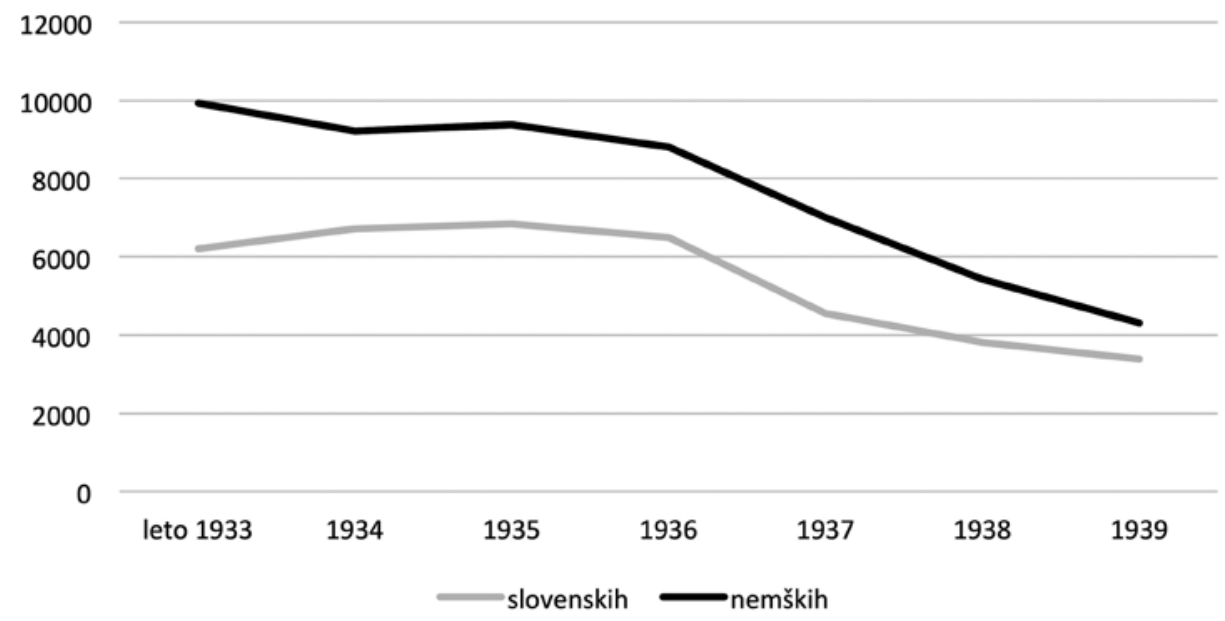

\section{Prosvetna katoliška knjižnica}

V Mariboru je delovala tudi knjižnica Prosvetne zveze, ${ }^{47}$ ki jo je skupaj s čitalnico Slovenska krščanska socialna zveza ${ }^{48}$ odprla spomladi 1923 v Lekarniški ulici. ${ }^{49}$ $\mathrm{V}$ prvem letu delovanja je bilo le 38 izposojevalnih ur. $\mathrm{V}$ tem času si je 46 članov izposodilo in prebralo $441 \mathrm{knjig.} \mathrm{Slab} \mathrm{obisk} \mathrm{je} \mathrm{povzročilo} \mathrm{dejstvo,} \mathrm{da} \mathrm{je} \mathrm{bila} \mathrm{knjižnica} \mathrm{zelo}$ pomanjkljivo opremljena. Šele proti koncu leta se je toliko izpopolnila, da je lahko zadovoljila najnujnejše zahteve. Konec leta 1923 je razpolagala z 2.605 knjigami. Knjižnica je v naslednjih letih znatno pomnožila obseg knjig, toda zaradi pomanjkanja prostorov jo je bilo nemogoče celostno urediti.

Naslednje leto se je knjižnica preselila na Aleksandrovo cesto 6 (današnja Partizanska cesta), kjer je delovala v pisarni Prosvetne zveze. $Z$ odprtjem knjižnice Prosvetne zveze $\mathrm{v}$ palači Zadružne gospodarske banke je bilo zadoščeno željam in potrebam krščansko socialnih organizacij v Mariboru, ki so bile več kot deset let brez lastne centralne knjižnice. Prosvetna katoliška knjižnica je postala javna knjižnica in je bila mentorica ostalim knjižnicam katoliških društev v severovzhodni Sloveniji. ${ }^{50}$

Poleg leposlovnega oddelka je imela knjižnica še strokovni oddelek. Organizirano je imela tudi potovalno knjižnico, deset skupin po $25 \mathrm{knjig}$, ki jih je pošiljala v oddaljene

47 Podobno, kot so se liberalno usmerjena društva združila v Zvezo kulturnih društev (ZKD), so se katoliško usmerjena prosvetna društva združila v Slovensko krščansko socialno zvezo (od leta 1923 Prosvetno zvezo) v Mariboru.

48 SKSZ se je 6. 12. 1923 na XIII. občnem zboru preimenovala v Prosvetno zvezo.

49 ZAP, MD-II-2 fond Muzejsko društvo, Zapisnik 3. seje odbora SKSZ 25. 4. 1923.

50 Hartman, $\gg$ Knjižnice v Mariboru, $\ll 700$. 
podeželske kraje brez knjižnic. ${ }^{51}$ Osnovni namen knjižnic, ki jih je podobno kot Zveza kulturnih društev ustanavljala Prosvetna zveza, je bila skrb za izobrazbo vseh slojev. Tako je bilo v Prosvetno zvezo konec leta 1924 vključenih že 134 knjižnic, ki so imele 51.662 knjig.

Število knjig je naraščalo iz leta v leto. Poročevalec v Straži je 3. novembra 1924 zapisal, da je imela leta 1924 knjižnica 807 slovenskih leposlovnih del v 1.132 zvezkih, 939 slovenskih poučnih del v 1.023 zvezkih, 495 nemških knjig, hrvaške in češke knjige pa tudi druge. ${ }^{52}$

Leta 1931 je knjižnica imela že 6.242 knjig, od tega 3.583 slovenskih, 406 srbohrvaških, 2.042 nemških in 211 drugih. $V$ tem letu je knjižnico obiskalo 7.900 bralcev, ki so si izposodili 12.901 knjigo. Imela je 802 člana, med njimi je bilo 16 odstotkov intelektualcev, 30 odstotkov dijakov, 41 odstotkov meščanov, 10 odstotkov delavcev in 2 odstotka kmetov.

Leta 1929 je knjižnica dobila novo ime, to je Prosvetna knjižnica, in tudi prvega redno zaposlenega knjižničarja Franca Sušnika, ki jo je vodil vse do druge svetovne vojne.

Graf 4: Število izposojenih del v Prosvetni knjižnici glede na izobrazbeno strukturo izposojevalcev in jezik leta 1934

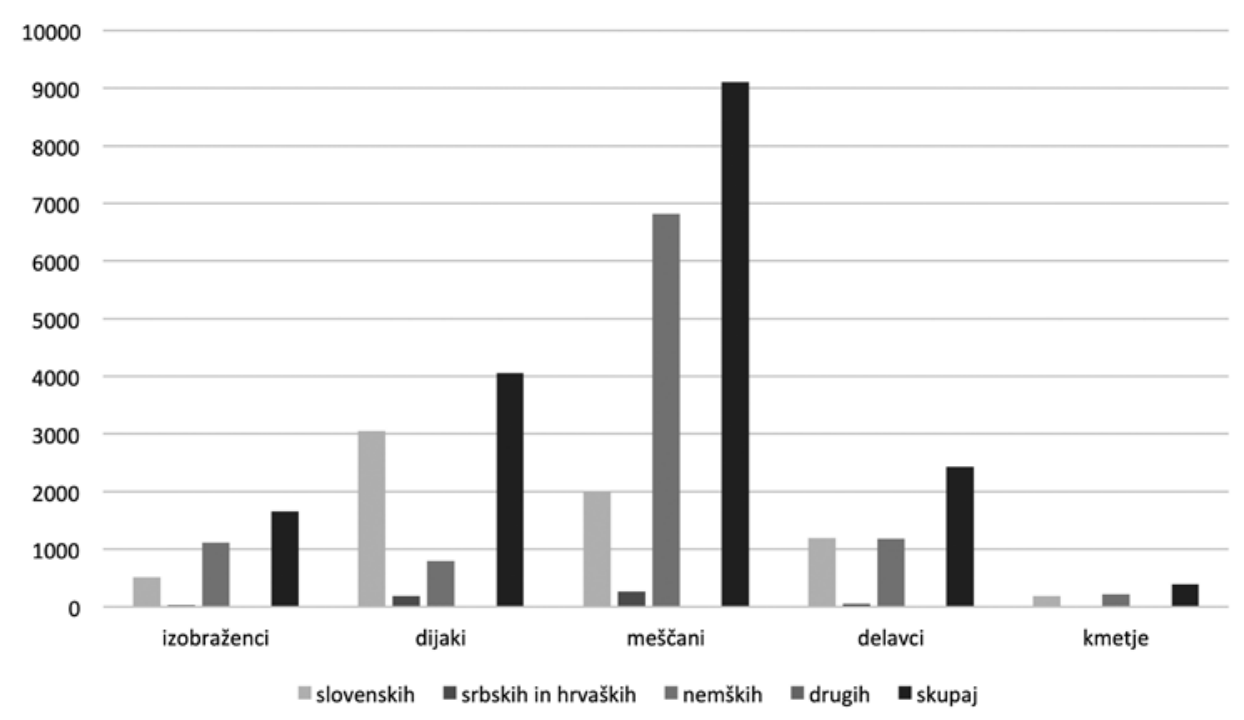

Primerjava poročil, ki so bila objavljena v že omenjenih letnih poročilih Prosvetne knjižnice za leto 1934 in leto 1937, kaže, da so Mariborčani radi zahajali v Prosvetno knjižnico in da je imela vpliv na kulturno osveščanje ljudi. Izobraženci so najpogosteje segali po nemških delih. Med izposojenimi knjigami so prevladovali romani. Sledila so

51 »Otvoritev knjižnice Prosvetne zveze v Mariboru, «Slovenski gospodar, 13. 8. 1925, 3.

$52 \gg$ Knjižnica Prosvetne zveze v Mariboru, « Straža, 3. 11. 1924, 3. 
dela v slovenščini, med njimi so prevladovali romani. Le redki so segali po poeziji. Med skupaj 17.632 izposojenimi knjigami so izposodili le $106 \mathrm{knjig}$ poezije.

Dijaki so najpogosteje segali po slovenskih delih. Opazno je, da so to že bile generacije, ki so nemščino razumele slabo ali pa je sploh niso več. Dijaki so si izposodili $3.063 \mathrm{knjig}$, med katerimi je bilo največ romanov. Sledila so izposojena dela v nemščini. Skupaj so si izposodili 792 knjig. Nasprotno je med meščani opazna močna prisotnost nemščine, saj so daleč najpogosteje segali po nemških delih. Skupaj so si izposodili kar $6.824 \mathrm{knjig}$. Najbolj iskani so bili romani, po katerih so večinoma segale ženske. Delavci so izbirali slovenske knjige (skupaj so si izposodili 1.203 slovenske knjige) in tudi nemške knjige (skupaj so si izposodili 1.186 knjig). Med bralci so bili bolj vneti moški, oboji pa so najpogosteje segali po romanih. Kmetje so bolj redko zašli v knjižnico. Skupaj so si izposodili 393 knjig, od tega nekoliko več nemške literature.

Graf 5: Skupno število izposojenih knjig v letu 1934 glede na jezik

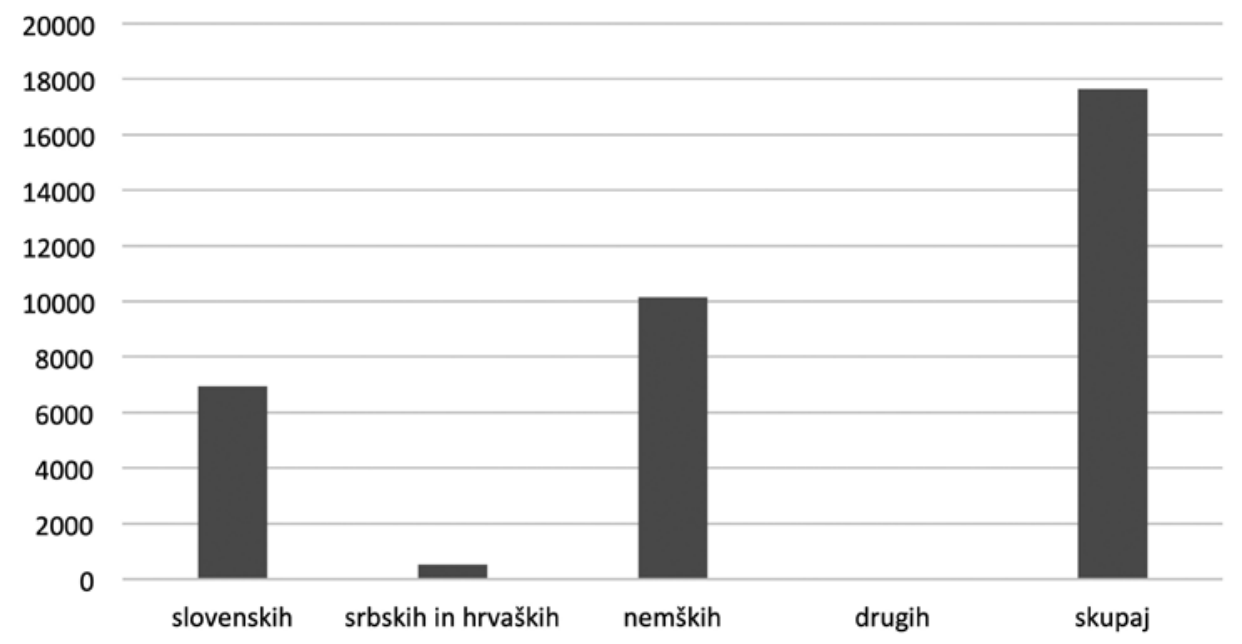

1080 članov je skupaj prebralo $17.632 \mathrm{knjig}$. Bralci so si najpogosteje izposojali nemško literaturo (izposojenih $10.132 \mathrm{knjig}$ ) in slovensko (izposojenih $6.942 \mathrm{knjig}$ ).

Tudi v tem letu so izobraženci največ segali po nemških delih. Izposodili so si 1.517 nemških knjig (leta $19341.117 \mathrm{knjig}$ ). Med izposojenimi knjigami so tudi v tem letu prevladovali romani. Sledila so izposojena dela v slovenskem jeziku. Skupaj so si izposodili 622 knjig (leta 1934507 knjig), med njimi le 18 srbskih ali hrvaških del.

Dijaki so najpogosteje segali po slovenskih delih. Izposodili so si 6.030 slovenskih knjig (leta $19343.063 \mathrm{knjig}$ ). Najpogosteje so izbirali romane, najbolj vneti bralci pa so bili fantje. Med meščani je bila nemščina še vedno bolj prisotna kot slovenščina, toda razmerje se je počasi enačilo. Vletu 1937 so si izposodili nekaj več nemških knjig kot leta 1934 (leta 19376.958 nemških knjig, leta 19346.824 knjig). Najbolj iskani so bili tudi to leto romani. Izposodili so si nekaj več slovenske literature (leta 19372.646 
knjig, leta 19342.000 knjig). Skupaj je bilo izposojenih 9.678 knjig. Tudi tega leta je med bralci mogoče najti več oseb ženskega spola.

Graf 6: Število izposojenih del v letu 1937 glede na izobrazbeno strukturo izposojevalcev in jezik

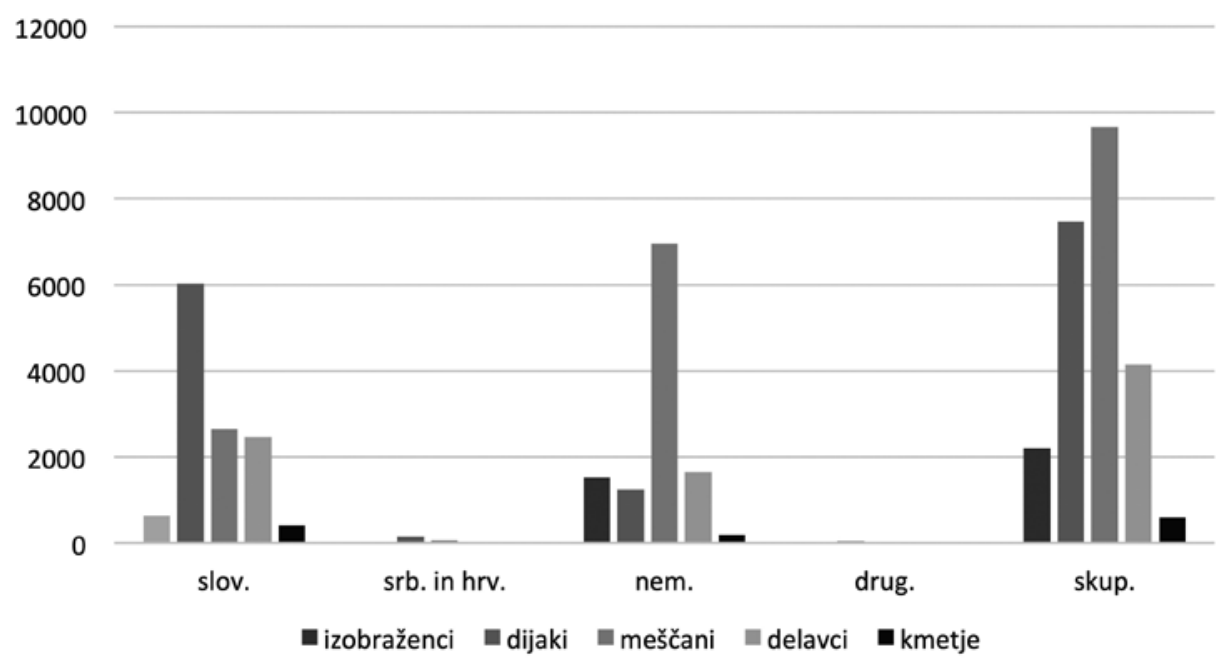

Graf 7: Skupno število izposojenih knjig v letu 1937 glede na jezik

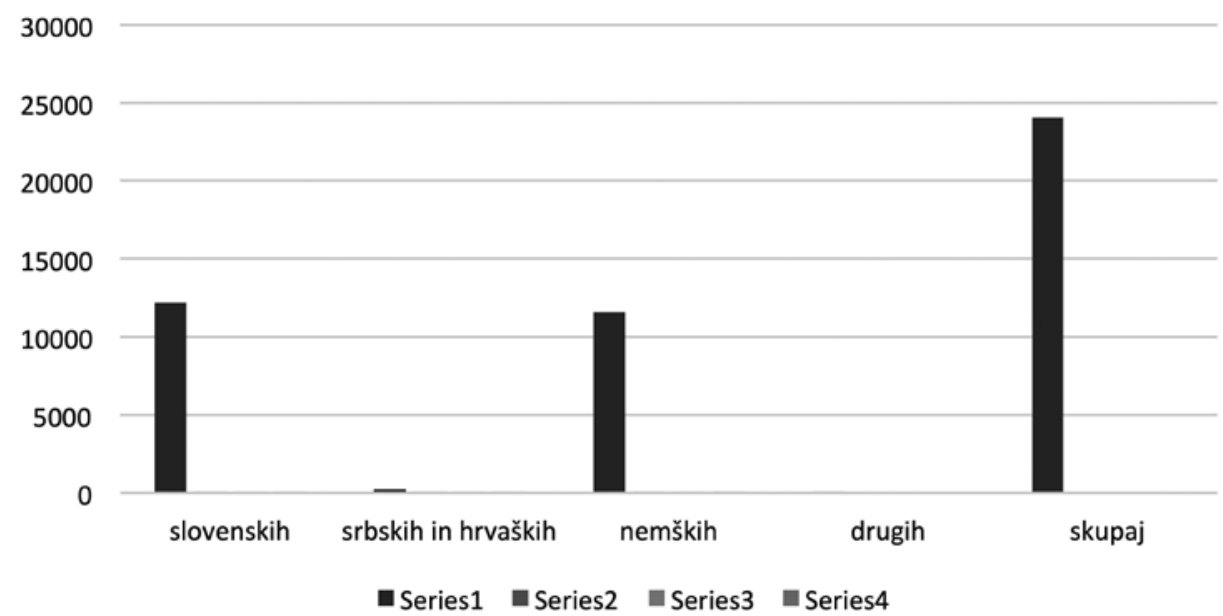

Delavci so v letu 1937 bolj segali po slovenskih knjigah. Skupaj so si izposodili 2.464 knjig (leta 19341.203 knjige). Izposodili so si 1.645 nemških knjig (v letu 1934 $1.186 \mathrm{knjig}$ ). Med izposojevalci so bili tudi tokrat bolj vneti moški. Kmetje so znova bolj redko zahajali v knjižnico. Skupaj so si izposodili 591 knjig (leta 1934393 knjig). 
Če je bila izposoja leta 1934 med slovensko in nemško literaturo približno enaka, so v letu 1937 bolj segali po delih slovenskih avtorjev (404 izposojene knjige, od tega le 185 nemških).

1.515 članov oziroma 13.099 bralcev si je izposodilo skupaj 24.076 knjig. Posebej zanimivo in pomembno je dejstvo, da so si bralci izposodili več slovenskih knjig (skupaj 12.176 knjig, leta 19346.942 knjig) kot nemških (skupaj izposojenih 11.563 nemških del, leta 1934 pa kar $10.132 \mathrm{knjig}$ ). Zanimivo je tudi dejstvo, da so bralci zelo redko segali po srbski in hrvaški literaturi. Izposodili so si samo 242 knjig (leta 1934 $528 \mathrm{knjig}$ ). Še redkeje so segali po literaturi v drugih jezikih (le $95 \mathrm{knjig}$, leta 193430 knjig). ${ }^{53}$

Iz navedene statistike lahko razberemo pomen Prosvetne knjižnice. Knjižnica je venomer napredovala. Tako je imela leta 1937 že pet potovalnih knjižnic, ki so bile nenehno na poti po podeželju. Leta 1939 jih je bilo že deset.

Zadnji uradni podatki o Prosvetni knjižnici so iz avgusta 1940. Takrat je imela $8.919 \mathrm{knjig}$, polovica knjig je bila slovenskih. Leta 1941 je namreč Prosvetno knjižnico doletela ista usoda kot ostale knjižnice v Mariboru. Približno polovico knjig so zadržali bralci, ostale pa so morale v zbirališča v Maribor, od tam pa v uničenje ali pa v Štajersko deželno knjižnico v Gradcu.

\section{Knjižnica Delavske zbornice}

29. junija 1919 je bila v Mariboru ustanovljena podružnica ljubljanske Svobode, matice podružnic po Sloveniji, ki je po prevratu nasledila delavsko kulturno društvo Vzajemnost izpred prve svetovne vojne. ${ }^{54}$

Mariborsko delavsko kulturno društvo Svoboda je leta 1925 ustanovilo knjižnični odsek, ki pa je zaradi majhnega števila knjig bolj slabo deloval. Konec leta 1926 je podružnica Delavske zbornice v Mariboru v svojih tajniških prostorih na Rotovškem trgu odprla čitalnico. V poslopju okrožnega urada za zavarovanje delavcev (danes Slomškov trg 6) v pritlični sobi na dvorišču so bili na razpolago slovenski, hrvaški, srbski in drugi tuji dnevniki ter vse pomembnejše slovenske in tuje socialne politične revije. ${ }^{55}$ Čitalnica je na Rotovškem trgu delovala skoraj leto dni, nato pa se je preselila na desni breg Drave, v palačo Pokojninskega zavoda na Trgu kralja Petra (danes Trg revolucije). ${ }^{56}$

Leta 1928 je prosvetni odsek Delavske zbornice v Ljubljani po zgledu svoje ljubljanske knjižnice preuredil tudi mariborsko. Poleg knjižnice Strokovne zveze in

53 Podatki iz letnih poročil: PAM, MOM, š. 424, št. spisa 7810, Prosvetna knjižnica v Mariboru s podatki o delu v letu 1935. PAM, MOM, š. 442, št. spisa 9306, Poročilo Prosvetne knjižnice v Mariboru za leto 1936. PAM, MOM, š. 456, št. spisa 9102, Poročilo za leto 1937.

54 Mariborska Svoboda, ki si je našla zavetje pri drugih delavskih društvih v Ljudskem domu na Ruški cesti, je imela različne odseke, ki so delovali bolj ali manj uspešno.

$55 \gg$ Nova čitalnica v Mariboru, « Delavska politika, 22. 12. 1926, 4.

$56 \gg$ Preselitev čitalnice Delavske zbornice, « Mariborski večernik Jutra, 16. 1. 1928, 1. 
organizacije tipografov se je novi knjižnici Delavske zbornice priključila knjižnica Svobode (s pridržkom, da ostane njena last). Ob odprtju 23. junija 1928 je bilo bralcem na razpolago okrog 3.000 knjig. ${ }^{57}$

Knjižnica, ki je bila namenjena predvsem delavcem in nameščencem, je že v prvih treh mesecih delovanja kazala dobre rezultate. Do konca septembra so beležili 241 članov, 1.405 obiskov, izposojenih knjig pa je bilo skupaj 2.568, med temi 2.318 leposlovnih, 153 znanstvenih, 1.599 nemških, 918 slovenskih in 64 srbskih ter hrvaških. ${ }^{58}$ Za delavsko izobrazbo so bili v čitalnici na razpolago tudi vsi slovenski, več nemških ter srbskih in hrvaških časopisov.

6. januarja 1929 je kralj Aleksander I. uvedel diktaturo. Sledili so različni ukrepi $\mathrm{v}$ smislu zakona o zaščiti javne varnosti in reda v državi. Tako so začeli nadzorovati tudi knjižnice, in sicer s treh vidikov: 1. glede na državno patriotično vsebino knjig, 2. glede na socialnopolitično smer s posebno pozornostjo na revolucijsko in komunistično tendenco ter 3 . glede na moralno kvarni vpliv. Nadzorniki so imeli nalogo preverjati izvajanje določil. ${ }^{59}$ Ker je bila mariborska knjižnica Delavske zbornice zaradi svoje vsebinske zasnove, zlasti spričo marksistične in socialnokritične literature, trn v peti novim določilom, so jo kmalu zadeli oblastni ukrepi. Tako je po nalogu banske uprave v Ljubljani mariborski policijski komisariat 4. decembra 1929 knjižnico zaradi »neustrezne « literature zapečatil. Izdali so seznam knjig, ki jih je bilo treba izločiti. Vse knjige, ki so imele protidržavni značaj in so propagirale komunizem, so odstranili. Odstranili pa so tudi socialno literaturo. Knjižnico so ponovno odprli 24. decembra istega leta. Zaradi opisanega dogajanja je število članov upadlo.

Graf 8: Primerjava izposoje knjižnice Delavske zbornice in Ljudske knjižnice v letih 1929 in 1930

25000

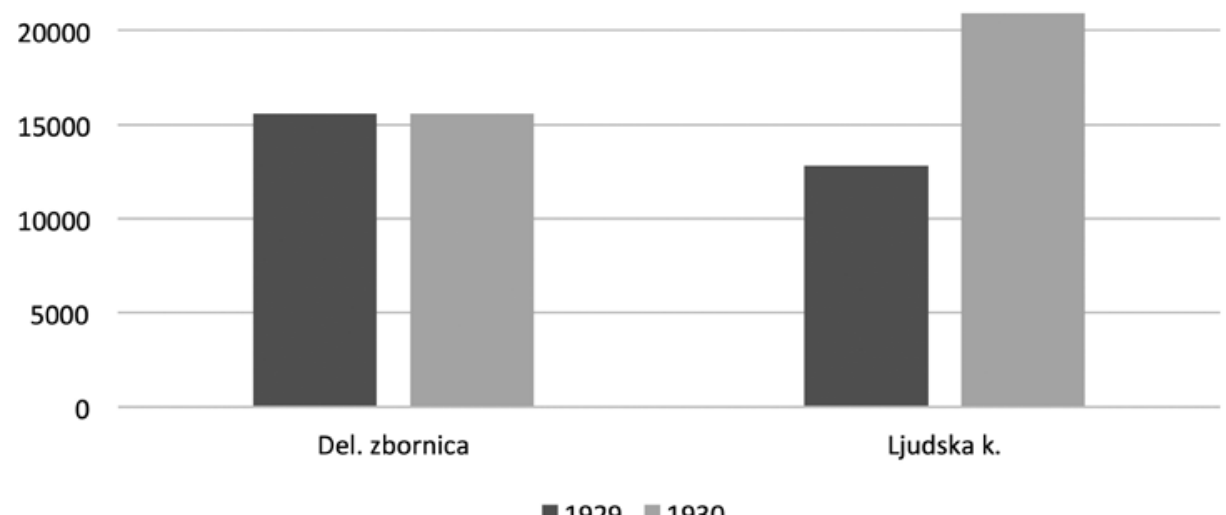

$\square 1929=1930$

$57 \gg$ Delavska knjižnica v Mariboru, « Jutro, 26. 6. 1928, 4.

58 »Knjižnica prosvetnega odseka Delavske zbornice, « Delavska politika, 6. 10. 1928, 3.

59 Avgust Pirjevec, Knjižnice in knjižničarsko delo (Celje: Družba Sv. Mohorja, 1940), 124. 
V prvem celoletnem koledarskem poslovanju, torejleta 1929, je knjižnica Delavske zbornice v kategoriji izposoje že prehitela Ljudsko knjižnico. Ker je bil politični položaj po letu 1930 za Ljudsko knjižnico ugodnejši, se je povzdignila nad knjižnico Delavske zbornice, toda le za kratek čas. V naslednjih letih je namreč knjižnica Delavske zbornice vztrajno krepila svojo premoč, Ljudska knjižnica pa je krnela. ${ }^{60}$

Mariborska knjižnica Delavske zbornice se je vse bolj uveljavljala kot kulturno središče delavcev in izobražencev. Skromni prostori v palači Pokojninskega zavoda na Trgu kralja Petra so postali pretesni, zato se je knjižnica leta 1931 preselila v moderno stavbo Okrožnega urada za zavarovanje delavcev in ekspoziture Delavske zbornice v Sodni ulici (danes Ulica talcev). Knjižnica je združila dotedanji knjižnici Svobode in strokovnega tajništva, dopolnjevala pa se je iz ljubljanske centrale, ki se je gmotno napajala iz zakonsko določenih prispevkov. ${ }^{61}$

Uredili so tudi potujočo knjižnico, namenjeno nameščencem ruške tovarne dušika. Tovarniški tovornjak je enkrat tedensko pripeljal nove knjige, prebrane pa odpeljal. Izposoja knjig je vztrajno naraščala. Vrhunec delovanja je knjižnica dosegla vletu 1936, ko je izposodila 42.590 knjig (od tega 24.687 nemških, 16.032 slovenskih). V letu 1937 je izposoja ostala skoraj enaka, obsegala je 42.230 knjig (od tega 24.332 nemških in 16.251 slovenskih).

Vzporedno z rastjo knjižnice se je spreminjal politični položaj v državi. Lipolda je na čelu mariborske občine zamenjal nekdanji župan dr. Alojzij Juvan. ${ }^{62}$ Krepiti so se začele tiste politične sile, ki delavskim strokovnim organizacijam, posredno pa tudi delavskim knjižnicam, niso bile naklonjene. Tako so bila 13. julija 1935 po celjskem zletu razpuščena socialistična delavska kulturna društva Svobode po Sloveniji. Novembra 1936 so bili opravljeni ponovni pregledi knjig, ker je Delavska fronta obsodila knjižnico Delavske zbornice, da zastruplja mladino z marksistično literaturo. ${ }^{63}$ Posledica tega je bil padec izposoje. ${ }^{64}$

Notranje težave in vojna psihoza, ki je ljudi odtegovala od branja, so povzročile, da je dejavnost mariborske knjižnice Delavske zbornice popustila. Leta 1939 je izposodila le še 33.977 knjig, obiskovalcev je bilo 17.662, članov pa 4.000. V skladih je imela okrog 13.000 knjig. ${ }^{65}$

Potem ko so nemške čete 9. aprila okupirale Maribor, je knjižnico Delavske zbornice doletela ista usoda kot vse ostale. Nacisti so jo zaplenili in uničili.

Knjižnica Delavske zbornice je v prvih letih, ko je imela največ obiskovalcev iz delavstva, izposodila veliko slovenskih knjig. Ko je začelo vanjo zahajati vedno več intelektualcev, je poskočilo povpraševanje po nemških knjigah, zato so knjižnici Delavske zbornice očitali, da ponemčuje. Število izposojenih slovenskih knjig je proti

60 Bruno Hartman, »Delavske knjižnice v Mariboru do druge svetovne vojne, « Časopis za zgodovino in narodopisje 51, št. 2 (1980): 335-37.

61 Hartman, $\gg$ Knjižnice v Mariboru, $\ll 701$.

62 Darko Friš in Nina Gostenčnik, »Dr. Alojzij Juvan - drugič na čelu mariborske mestne občine (1935-1941), « Acta Histriae 26, št. 1 (2018): 181.

$63 \gg$ V knjižnici Delavske zbornice, « Delavska politika, 21. 11. 1936, 3.

64 »njižnica Delavske zbornice - odraz kulture,« Delavska politika, 5. 7. 1938, 4.

$65 \gg$ Knjižnice - kulturni barometer, « Večernik, 8. 8. 1940, 4. 
letu 1941 rastlo. Obiskovalci so vsa medvojna leta le malo povpraševali po srbskih in hrvaških delih. Bralci so radi segali po romanih, leposlovju in knjigah za sprostitev.

Graf 9: Število izposojenih del knjižnice Delavske zbornice v Mariboru

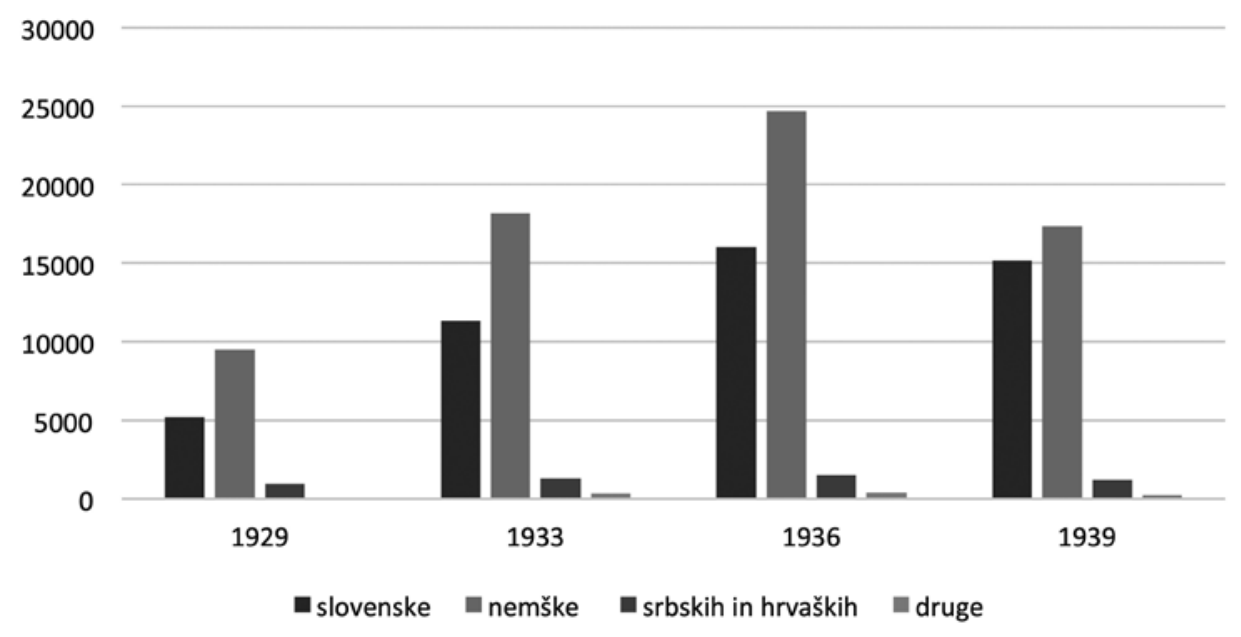

Graf 10: Število izposojenih del v knjižnici Delavske zbornice v Mariboru v letih 1929, 1933, 1936 in 1939

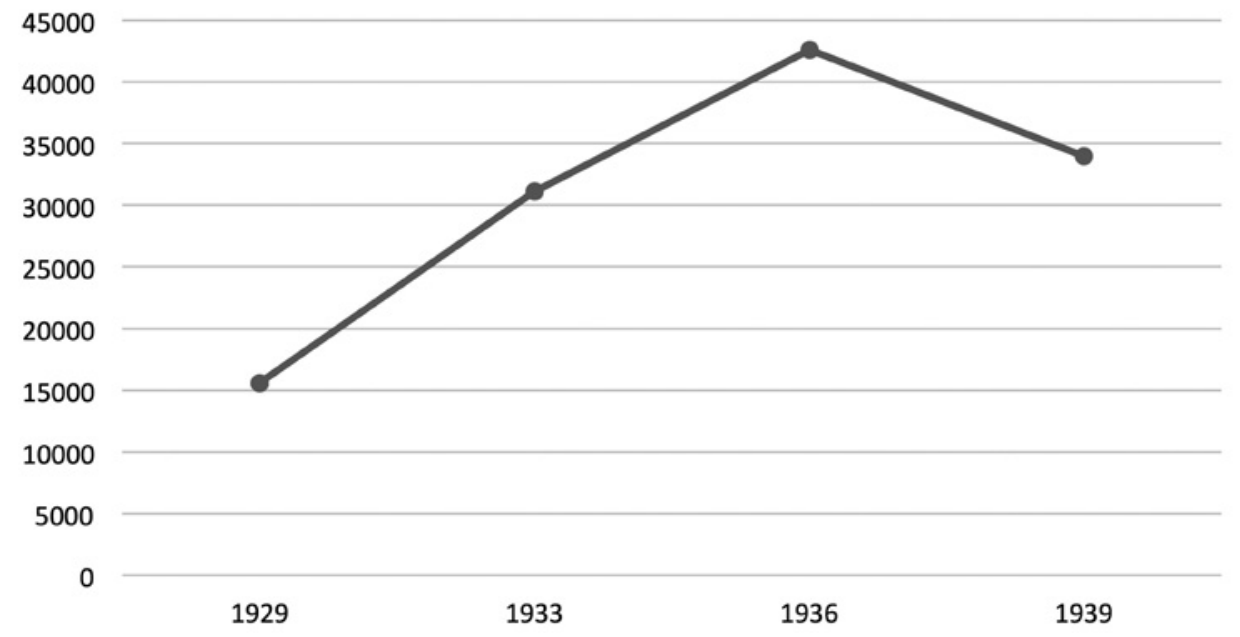

Knjižnica je bila na tekočem z najsodobnejšo slovensko literaturo. Od slovenskih pisateljev so največ brali Cankarja, Seliškarja, Finžgarja, Bevka in Jurčiča. Med slovensko prevedeno literaturo je bilo največ povpraševanja po knjigah o Tarzanu in knjigah Karla Maya. Izposoja znanstvenih knjig je bila po drugi strani zelo nizka, kar so opravičevali s tem, da je Maribor industrijsko mesto. Med znanstvenimi knjigami so bralci 
največ segali po potopisnih in narodoznanstvenih delih ter po knjigah o aktualnih političnih in socialnih vprašanjih.

Prikaz socialne strukture bralcev nam pove, da je bilo največ ročnih delavcev (624), veliko je bilo še delavcev kovinske stroke, tekstilnih delavcev, tipografov in knjigovezov, krojačev, mizarjev, čevljarjev ter 189 nekvalificiranih delavcev. Med izobraženci je bilo 323 dijakov in študentov, 164 uradnikov, 64 učiteljev itd. Tudi socialna struktura bralcev kaže na to, da so med obiskovalci prevladovali delavci, ki so manj segali po znanstveni literaturi.

Leta 1928 je knjižnica izposodila 6.083 knjig, leta 1936 že rekordnih 42.590 knjig in nato leta 1939 nekoliko manj - 33.977, leta 1940 pa spet več, kar $42.473 .{ }^{66}$ Vedno bolj je naraščala izposoja slovenskih knjig v primerjavi z nemškimi. ${ }^{67}$

Leta 1925 je bila ustanovljena podružnica Svobode tudi na Studencih, ki si je leta 1930 uredila knjižnico v kulturnem domu. $S$ knjižnico pa je razpolagala tudi podružnica Svobode na Pobrežju.

\section{Knjižnica Zveze kulturnih društev}

Podobno kot so se katoliško usmerjena prosvetna društva združila v Prosvetno zvezo, so se povezala tudi društva tako imenovanega naprednega, liberalnega dela slovenskega meščanskega razreda, in sicer leta 1920 v Zvezo kulturnih društev (ZKD). Vanjo so se začele vključevati že obstoječe knjižnice, čitalnice, prosvetni odseki sokolskih društev, narodna, bralna, učiteljska, študentska, pevska, podporna, športna in druga podobna društva. ${ }^{68}$ Oktobra 1925 so ZKD razdelili na dva dela; za ljubljansko in mariborsko oblast. ${ }^{69}$

V političnem pogledu se je zveza naslanjala na Samostojno demokratsko stranko, kasneje pa na njeno naslednico Jugoslovansko nacionalno stranko, ki sta bili centralistično jugoslovansko usmerjeni. Namen ZKD je označil njen mariborski predsednik Anton Skala s temi besedami: »Skupni smoter je vzgojiti naše ljudstvo viskreni, srčni kulturi; vzbuditi v njem zavest slovenstva, hrvatstva in srbstva, to je jugoslovanstva in na to vseslovanstva; dvigniti naše ljudstvo do pravega pojmovanja človečanstva. $\ll^{70} \mathrm{Zveza}$ je svoj narodni in prosvetno-kulturni program izvrševala zlasti na območju narodnostno ogrožene severne meje. S pomočjo njenih številnih včlanjenih društev so organizirali predavanja in tečaje (knjižničarskega, igralsko-režiserskega, gospodarsko-prosvetnega, zadružno-propagandnega, lutkarskega itd).

66 Hartman, »Delavske knjižnice v Mariboru, « 337-47.

67 »Delavske knjižnice v Sloveniji,« Vzajemna Svoboda, 2. 2. 1938, 31.

68 Ervin Dolenc, »Boj za množice - Zveza kulturnih društev, « v: Slovenska kronika XX. stoletja, ur. Marjan Drnovšek in Drago Bajt (Ljubljana: Nova revija, 1995), 246.

69 Zveza kulturnih društev je bila v primerjavi s katoliško Prosvetno zvezo bolj ohlapno organizirana, delovala je kot servis društev. Za idejno usmerjenost in vzgojo ni skrbela toliko kot Prosvetna zveza, ki je bila ideološko in organizacijsko trdnejša in učinkovitejša.

70 Anton Skala in Vekoslav Špindler, Prosvetno delo 1925-1930: ob petletnici Zveze kulturnih društev v Mariboru (Maribor: Zveza kulturnih društev, 1930), 2. 
Poleg teh prireditev pa je imela Zveza v programu tudi ustanavljanje knjižnic, kar ji je kljub finančnim težavam dobro uspevalo. Mariborska ZKD si je za glavno nalogo zadala ustanovitev nove velike centralne knjižnice v Mariboru. Na svojem sedežu v pisarni v Cankarjevi ulici 1 je imela knjižne omare, v katere je spravljala knjige, ki jih je dobivala kot darove. Na občnem zboru mariborske Slovanske čitalnice 2. julija 1929 je ZKD pod vodstvom svojega predsednika Antona Skale skušala prevzeti njeno Ljudsko knjižnico v svoje roke. Ustanovitev centralne knjižnice se ji ni posrečila. ${ }^{71}$

V petih letih (1925-1930) ji je uspelo ob knjižnicah, ki so bile last društev, ustanoviti še 42 javnih ljudskih knjižnic. ${ }^{72}$ Prvo knjižnico je ustanovila Zveza 13. junija 1926 na Teznem pri Mariboru. Ob petletnici Pevskega društva Zvon, 10. oktobra 1926, je bila ustanovljena druga knjižnica pri Sv. Duhu na Ostrem Vrhu; 20. januarja 1927 je tretjo knjižnico ustanovilo Tamburaško društvo Dravinja v Zbelovem pri Poljčanah, 27. februarja pa so odprli knjižnico Pevskega društva Zarja na Pobrežju; knjižnico Obmejnega zvona so ustanovili 6. marca v obmejnem Št. Ilju v Slov. goricah, 25. marca je svojo knjižnico dobilo Izobraževalno društvo v Lehnu na Pohorju, v maju pa je bila ustanovljena knjižnica v Krčevini pri Mariboru. Sledile so še novoustanovljene knjižnice v Šmartnem ob Paki, pri Sv. Ani v Slovenskih goricah in v Odrancih pri Beltincih v Prekmurju - to je bila tudi prva ljudska knjižnica, ki jo je Zveza ustanovila v Prekmurju. ${ }^{73}$ Ob koncu leta 1927 je imelo kar 82 društev lastne knjižnice, v katerih je bilo več kot 50.000 knjig. ${ }^{74}$ Vsaka knjižnica je imela prvotno 60 knjig. Knjižni fond je z vpisnino, izposojevalnino in s podporami postopoma porasel. Poleg knjižnic je imelo 30 društev tudi svoje čitalnice, $v$ katerih je bilo 150 različnih časopisov in revij.

Mreža knjižnic ZKD se je širila tudi v naslednjih letih. Leta 1933 je imelo lastne knjižnice 108 včlanjenih društev, poleg teh so imeli še 73 javnih potovalnih knjižnic, ki jih je ustanovila ZKD. ${ }^{75} \mathrm{~V}$ začetku leta 1934 je število teh naraslo na 78 , večinoma pa so bile na obmejnem ozemlju. ${ }^{76}$ Vrhunec svojega knjižničarstva je mariborska ZKD dosegla leta 1938, ko se je število knjižnic povzpelo na 240 s skupno 72.000 knjigami. $^{77}$

Zaradi spremenjenega političnega položaja v državi in svetu se je kasneje število društev zmanjšalo. Bližajoča se vojna in politična kriza $v$ državi sta vplivali tudi na bralce, ki so manj segali po knjigah.

ZKD v Mariboru pa ni le ustanavljala knjižnic, ampak je podeželskim knjižnicam pomagala tudi tako, da jim je pošiljala knjige, ki jih je dobila kot darila. Prirejala pa je tudi projekcije filmov in z izkupičkom kupovala nove knjige. Knjižnice, včlanjene v Zvezi, so tudi same pridobivale denar, predvsem z izposojevalnino, s katero so dopolnjevale svoje knjižne zbirke. Najbolj delovna in v svojem okolju najbolj vplivna je bila

71 UKM, Rokopisna zbirka, Slovanska čitalnica Maribor, Ms 201/IV/6. Zapisnik 68. občnega zbora mariborske Slovanske čitalnice 2. julija in 1. redne odborske seje 9. julija 1929.

72 Skala in Špindler, Prosvetno delo 1925-1930, 4.

73 »Deset novih žarišč napredka in prosvete na naši severni meji,« Mariborski večernik Jutra, 18. 6. 1927, 3.

$74 \gg$ Revija kulturnega dela ob meji,« Mariborski večernik Jutra, 9. 12. 1927, 3.

75 »Zborovanje naših naprednih kulturnih društev, « Mariborski večernik Jutra, 27. 3. 1933, 1.

76 PAM, MOM, š. 385, št. spisa 300. Zveza kulturnih društev pošilja dopis Mestnemu načelstvu Mariboru. Maribor, 9. januar 1934.

77 »Pionirji kulturnega in narodno obrambnega dela na naši meji,« Mariborski večernik Jutra, 25. 4. 1938, 2. 
Javna ljudska knjižnica Sokolskega društva na Studencih. S svojo knjižno zalogo in organizacijo se je postavila ob bok vodilnim javnim knjižnicam v Mariboru med svetovnima vojnama. Sokolske knjižnice so bile ustanovljene z namenom, da informirajo svoje bralce o sokolstvu, zato so zbirale literaturo o telesni vzgoji in ljudski prosveti. Nekatere so se dopolnile še z leposlovjem. Kot predvsem strokovne knjižnice niso imele veliko izposojevalcev.

Sokolsko društvo je bilo na Studencih ustanovljeno leta 1919. Že naslednje leto si je omislilo knjižnico, ki je sprva imela le 120 knjig. Do leta 1929 so knjižni fond povečali na 504 knjige, do leta 1932 pa že na 1.712 knjig. Konec leta 1932 se je uprava sokolske knjižnice na Studencih odločila, da knjižnico preoblikuje v javno, da bo na voljo vsem krajanom. Tako je tega leta izposodila čez 5.000 knjig. Knjižnični odbor si je močno prizadeval povečati knjižne sklade in pritegniti nove bralce. V naslednjem letu je izvedel nekaj akcij: nabiral je knjige, denarne prispevke, nakupoval je knjige in jih iskal tudi z oglasi po časnikih. Število knjig in obiskovalcev je stalno naraščalo. ${ }^{78}$ Tako je leta 1938 knjižnica imela že $5.643 \mathrm{knjig}$, leto prej pa si je 450 bralcev izposodilo 6.150 knjig. ${ }^{79}$ Tik pred drugo svetovno vojno je knjižnica imela nekaj več kot 8.000 knjig, bralci pa so imeli na razpolago še časopisje. Zaloga knjig se je stalno večala, saj so iz nabrane izposojnine takoj kupili knjižne novosti. V letu 1940 je bilo kupljenih 843 knjig, izposojenih pa kar 13.578 knjig. Tako je bil vsak sedmi Studenčan obiskovalec te knjižnice. ${ }^{80}$

Velika večina knjig je bila slovenskih, kar je bilo še posebej pomembno, saj so skoraj vse večje knjižnice imele večje število predvsem nemških knjig, kar je vplivalo tudi na narodno zavednost. Glavni obiskovalci knjižnice so bili predvsem delavci in mladina. Sokolska knjižnica na Studencih je zlasti med delavstvom opravljala pomembno kulturno poslanstvo $\mathrm{v}$ okolici mesta.

\section{Knjižnica nemške manjšine v Mariboru}

V društvenih prostorih na Strossmayerjevi 6 je od 1. septembra 1928 delovala ljudska in otroška knjižnica, kjer je bilo članom na razpolago veliko raznovrstnega branja, od znanosti do beletristike. ${ }^{81}$ Na voljo so bili tudi dnevni časopisi Jugoslavije, Nemčije, Češkoslovaške in Avstrije ter tudi najpomembnejše revije. Uredilo jo je Politično in gospodarsko društvo Nemcevv Sloveniji (Politischer und wirtschaftlicher Verein der Deutschen in Slowenien). Leta 1931 je knjižnico preuredila takrat ustanovljena podružnica Kulturbunda. ${ }^{82}$

\footnotetext{
78 Bruno Hartman, »Mariborska Zveza kulturnih društev in njene knjižnice, « Prispevki za zgodovino delavskega gibanja 23, št. 1-2 (1983): 89.

79 »Sokolska knjižnica v Studencih,« Mariborski večernik Jutra, 16. 4. 1938, 3.

80 »Kulturno delo studenške sokolske knjižnice, « Mariborski večernik Jutra, 23. 1. 1941, 7.

81 »Der 'Politische und wirtschaftliche Verein der Deutschen in Slowenien',« Marburger Zeitung, 2. 9. 1928, 6.

82 Hartman, »Knjižnice v Mariboru, « 701.
} 


\section{Šolske knjižnice in knjižnica Pedagoške centrale}

Kot posledica postopne preobrazbe ljudskih šol v slovenske šolske ustanove so nastajale tudi slovenske šolske knjižnice. V njih je prevladovala nemška literatura. Po odloku šolskih oblasti so nemška in slovenska dela, ki so povzdigovala habsburško monarhijo, odstranili iz knjižnic. Pomembno vlogo je imela zlasti knjižnica Pedagoške centrale. ${ }^{83}$ Najdragocenejše orožje v rokah društva je bila bogata strokovna knjižnica. Članom je bilo na razpolago tudi več pedagoških revij.

Francoski krožek in Društvo prijateljev angleškega jezika in prosvete sta ob pomoči francoskih in angleških vladnih institucij skrbela za francosko in angleško literaturo v svojih knjižnicah. ${ }^{84}$

Leta 1934 pa je v Mariboru začel delovati tudi Slovenski bralni krožek, ki je vsakomur nudil možnost branja slovenskih in ostalih jugoslovanskih revij. Nudil je mesečnike in tednike leposlovne, znanstvene, zabavne, športne in druge vsebine ter ženske in družinske revije. Tako je krožek s pomočjo svojih revij seznanjal naročnike z vsem, kar se je dogajalo doma in v tujini v literaturi, znanosti, športu, umetnosti in družabnem življenju.

\section{Okupacija in medvojno obdobje}

Že v prvih mesecih okupacije so prenehale delovati vse slovenske organizacije in ustanove, upravo pa so ponemčili. Tako imenovani Ukinitveni komisar za društva, organizacije in združenja na Spodnjem Štajerskem, ustanovljen v prvih dneh okupacije, je takoj po začetku zasedbe ukinil vsa kulturna in narodnoobrambna društva. Najprej torej tista, ki so bila za dosego okupatorjevih ciljev najbolj nevarna in neprijetna. Nato so $v$ treh letih sistematično ukinili še ostala strokovna, športna, verska in politična združenja, ustanovili pa tudi nekaj novih nemških. Lastnina ukinjenih društev in organizacij je bila v največ primerih zaplenjena v korist nemške države ali namenjena za »izgradnjo « Spodnje Štajerske. V največ primerih jo je prevzela pokrajinska blagajna NSDAP v Gradcu, nekajkrat pa tudi Štajerska domovinska zveza. Premoženje ukinjenih gasilskih društev so nasledile občine, v katerih je društvo delovalo. Samo na širšem področju mesta Maribor je bilo ukinjenih več kot 600 društev, na slovenskem Štajerskem pa okrog 3.600 društev in organizacij..$^{85}$

83 Leta 1920 se je na predlog Gustava Šiliha ustanovil Pedagoško-didaktični odsek Učiteljskega društva za Maribor in bližnjo okolico. Leta 1921 se je odsek osamosvojil v Pedagoško-didaktični krožek. Vedno večje zanimanje je povzročilo, da se je delokrog društva razširil na bivšo Mariborsko oblast, pozneje pa na vso Dravsko banovino; zato je bila potrebna preureditev društva v Pedagoško centralo. Pedagoška centrala je združevala predvsem poklicne vzgojitelje. Njen namen je bil, da je seznanjala javnost $\mathrm{z}$ izsledki, stremljenji in stanjem moderne pedagogike. $\mathrm{V}$ ta namen so prirejali pedagoške tečaje, pedagoške tedne, predavanja in ekskurzije.

84 Hartman, »Knjižnice v Mariboru, 2701.

85 Jure Maček, Ukinitveni komisar za društva, organizacije in združenja na Spodnjem Štajerskem (Maribor: Pokrajinski arhiv, 2004), 8-12. 
Prav tako so bile uničene mnoge šolske, društvene in tudi zasebne knjižnice. Nadzor nad zaplembo slovenske literature je prevzel nacionalno-politični referent pri šefu civilne uprave, Helmut Carstanjen. Med velikimi knjižnicami, ki jih je okupator skoraj popolnoma uničil, so bile Knjižnica delavske zbornice, Ljudska knjižnica in Prosvetna knjižnica.

Periodične publikacije Študijske knjižnice je leta 1941 ob nacistični okupaciji doletela enaka usoda kot ostalo gradivo. Časopisje so odpeljali v Gradec in za cel vagon so ga repatriirali šele 4 . septembra $1946 .{ }^{86}$

Dotedanji ravnatelj Študijske knjižnice Janko Glazer je bil odpuščen in kasneje izgnan v Srbijo. Nasledila ga je ruska emigrantka Elizabeta Obolenska, ki je v knjižnici ostala do marca $1945 .^{87}$

\section{Zaključek}

Maribor je po prvi svetovni vojni doživel velike družbenopolitične spremembe. V novi državi Kraljevini SHS je izgubil svoj prejšnji gospodarsko-prometni položaj. Spremenili sta se narodnostna struktura prebivalstva in tudi družbena struktura mestnega prebivalstva, saj se je predvsem nemško uradništvo izselilo. V mesto so prišli novi priseljenci, največ s Primorskega. Več kot 10.000 Primorcev, kolikor jih je pribežalo $\mathrm{v}$ mesto in okolico pred fašističnim terorjem, je pomagalo zapolniti vrzel $\mathrm{v}$ gospodarstvu in upravi po izselitvi Nemcev. $S$ svojim delovanjem so močno razgibali družbeno in družabno življenje $\mathrm{v}$ mestu in tako ob domačinih odločilno prispevali $\mathrm{k}$ slovenski podobi mesta, hkrati pa krepili narodno zavest Mariborčanov, saj so bili v glavnem močno jugoslovansko orientirani. H kulturni razpoznavnosti mesta so prispevali tudi Nemci. Ti so bili vsaj do srede tridesetih let v glavnem tolerantni do nove oblasti. S svojim kulturnim delovanjem so bogatili tudi Slovence. Poleg Nemcev so tudi drugi narodi v mestu, predvsem Čehi, Rusi, Hrvati, Srbi in drugi, s svojim kulturnim deležem pomagali k pravi svetovljanski podobi mesta. Prav narodno mešana družba je dajala mestu pravi čar in prispevala $\mathrm{k}$ njegovi novi identiteti.

Iz predvojne znanstvene knjižnice Zgodovinskega društva za slovensko Štajersko se je leta 1921 izoblikovala splošna znanstvena Študijska knjižnica, ki ji je svoje fonde pridružilo tudi Muzejsko društvo. Študijska knjižnica je postala leta 1925 mestna ustanova, za katero je do okupacije skrbela mariborska mestna občina. Pod strokovnim vodstvom Janka Glazerja je postala prva in največja slovenska znanstvena knjižnica na Štajerskem. Družbenopolitična in ideološka delitev je privedla do tega, da je bilo med obema vojnama javno knjižničarstvo v Mariboru razdeljeno v tri politične tabore: liberalnega z Ljudsko knjižnico, katoliškega s Prosvetno katoliško knjižnico in socialističnega s knjižnico

86 Bruno Hartman, »Petinsedemdeset let Univerzitetne knjižnice Maribor (1903-1978), « v: Univerzitetna knjižnica Maribor 1903-1978: jubilejni zbornik: ur. Bruno Hartman et al. (Maribor, Obzorja, 1978), 82.

87 Marjan Žnidarič, Do pekla in nazaj, Nacistična okupacija in narodnoosvobodilni boj v Mariboru (Maribor: Muzej narodne osvoboditve, 1997), 18. 
Delavske zbornice. Iz predvojne liberalne Ljudske knjižnice se je ta pod vodstvom dr. Avgusta Reismana razvila $\mathrm{v}$ pomemben center družabnega življenja $\mathrm{v}$ mestu. V letih 1931-1932 je imela okrog 13.000 zvezkov in letno 24.000 obiskov. Zaradi konkurence dnevnega časopisja in revij ter knjižnice Delavske zbornice je v tridesetih letih izgubljala vpliv v javnosti. V istem obdobju je naraščala moč Delavske knjižnice. S pestrim izborom literature in dobro organizacijo je postala kljub političnim pritiskom najboljša javna ljudska knjižnica v Mariboru. Leposlovje so predstavljala socialno kritična dela. Znanstvena in strokovna literatura je slonela na marksistični filozofiji in s tem vplivala na delavsko revolucionarno misel. Katoliški tabor je leta 1929 zaradi »konkurenčne « Ljudske knjižnice in Delavske knjižnice pod vodstvom Franca Sušnika prenovil Prosvetno knjižnico. Zveza kulturnih društev je na območju narodnostno ogrožene severne meje s številnimi knjižnicami opravljala narodnoprebudno in kulturno poslanstvo. Knjižnice so imeli tudi mariborski šolski zavodi in številna društva.

Primerjava med knjižnicami nam pove, da je Študijska knjižnica imela največje število knjig in da je bila v njej tudi največja izposoja. Največ članov je imela knjižnica Delavske zbornice, kjer je bilo tudi največ obiskovalcev. Med izposojenimi knjigami je bila pri Študijski in Prosvetni knjižnici več kot polovica slovenskih, pri ostalih dveh knjižnicah pa je bila izposoja nemških knjig nekoliko večja. Ker je bila domača književna produkcija vedno večja - bilo je tudi vedno več prevodov -, je mogoče opaziti upad povpraševanja po nemških knjigah. $\mathrm{K}$ temu je pripomoglo tudi dejstvo, da zlasti dijaška mladina $\mathrm{v}$ tridesetih letih ni več obvladala nemščine. Med uporabniki v Študijski knjižnici je bilo 60 odstotkov dijakov in visokošolcev. Srednji družbeni sloj je izbiral dela za zabavo. V Prosvetno knjižnico so zahajali predvsem katoliški intelektualci, dijaki, največ pa srednji družbeni sloj. Obiskovalci knjižnice Delavske zbornice so bili večinoma delavci, nekaj je bilo tudi intelektualcev. Bralci so segali po delih slovenskih pisateljev, izposojali so si politično in sociološko literaturo, potopise idr. V Ljudsko knjižnico so zahajali bralci srednjega sloja in tudi manj zahtevni bralci. Tudi svetovni dogodki so vplivali na izposojo knjig; tako so v času sudetske krize leta 1938 bralci najpogosteje izbirali češke pisce. Pred izbruhom druge svetovne vojne so brali dela angleških pisateljev in politikov pa tudi dela nacističnih piscev.

\section{Viri in literatura}

\section{Arhivski viri}

- PAM - Pokrajinski arhiv Maribor:

- PAM, fond Mestna občina Maribor.

- PAM, fond Slovanska čitalnica Maribor.

- UKM - Univerzitetna knjižnica Maribor:

- UKM, Rokopisna zbirka, Slovanska čitalnica, Maribor, Ms 201/IV, 6.

- ZAP - Zgodovinski arhiv Ptuj:

- ZAP, MD-II-2 fond Muzejsko društvo. 


\section{Časopisni viri}

- Delavska politika, 1926, 1928, 1933, 1936, 1938, 1941.

- Jutro, 1926, 1928.

- Marburger Zeitung, 1928.

- Mariborski večernik Jutra, 1927, 1928, 1931, 1938.

- Slovenec, 1927, 1938.

- Slovenskigospodar, 1925.

- Straža, 1924.

- Tabor, 1921, 1927.

- Večernik, 1940.

- Vzajemna Svoboda, 1938.

\section{Literatura}

- Baš, Franjo. »Maribor v avstrijski ustavni dobi.« Časopis za zgodovino in narodopisje 38, št. 3 (1967): 184-243.

- Dolar, Jaro. Spomini: v preddverju literature. Maribor: Obzorja, 1995.

- Dolenc, Ervin. »Boj za množice - Zveza kulturnih društev«. V: Slovenska kronika XX. stoletja, ur. Marjan Drnovšek in Drago Bajt, 246. Ljubljana: Nova revija, 1995.

- Ferlež, Jerneja. »Prebivalstvo Maribora 1848-1991.« Studia Historica Slovenica 2, št. 1 (2002): 79-125.

- Friš, Darko. »Maribor po prevratu in vladni komisar dr. Josip Leskovar.« Studia Historica Slovenica 18, št. 1 (2018): 191-216.

- Friš, Darko. »Razmah in napredek Maribora v času županovanja dr. Josipa Leskovarja (19241928).« Acta Histriae 26, št. 1 (2018): 127-58.

- Friš, Darko in Nina Gostenčnik. »Dr. Alojzij Juvan - drugič na čelu mariborske mestne občine (1935-1941).« Acta Histriae 26, št. 1 (2018): 181-206.

- Glazer, Janko. Študijska knjižnica v Mariboru: zgodovina njenega nastanka. Maribor: Mariborska tiskarna, 1928.

- Glazer, Janko. »Študijska knjižnica v Mariboru. Zgodovina njenega nastanka.« V: Razprave, članki in ocene, ur. Viktor Vrbnjak. Maribor: Obzorja, 1993.

- Gostenčnik, Nina. »Dr. Franjo Lipold, mariborski mestni načelnik v letih od 1931 do $1935 . \ll S t u-$ dia Historica Slovenica 17, št. 3 (2017): 989-1028.

- Hartman, Bruno. »Petinsedemdeset let Univerzitetne knjižnice Maribor (1903-1978).« V: Univerzitetna knjižnica Maribor 1903-1978: jubilejni zbornik, ur. Bruno Hartman et al., Maribor, 1978.

- Hartman, Bruno. »Slovanska čitalnica v Mariboru in njeni knjižnici.« Časopis za zgodovino in narodopisje 50, št. 1-2 (1979): 295-340.

- Hartman, Bruno. »Delavske knjižnice v Mariboru do druge svetovne vojne.« Časopis za zgodovino in narodopisje 51, št. 2 (1980): 322-50.

- Hartman, Bruno. »'Südmarkini' knjižnici v Mariboru.« Časopis za zgodovino in narodopisje 54, št. 1-2 (1983): 145-53.

- Hartman, Bruno. »Mariborska Zveza kulturnih društev in njene knjižnice. « Prispevki za zgodovino delavskega gibanja 23, št. 1-2 (1983): 89-99.

- Hartman, Bruno. »Knjižnica mariborske realke (realne gimnazije) (1870-1941).« Časopis za zgodovino in narodopisje 56, št. 2 (1985): 139-62.

- Hartman, Bruno. »Knjižnice v Mariboru.«V: Maribor skozi stoletja. Razprave I, ur. Jože Curk, Bruno Hartman in Jože Koropec, 695-704. Maribor: Obzorja, 1991.

- Hartman, Bruno. »Dvoje nenavadnih mariborskih knjižničarjev.« Časopis za zgodovino in narodopisje 64, št. 2 (1993): 229-40. 
- Hartman, Bruno. Zgodovina slovenskega dramskega gledališča v Mariboru do druge svetovne vojne. Maribor: Založba Obzorja, 1996.

- Hazemali, David, Mateja Matjašič Friš, Ana Šela in Majda Schmidt. »Med priložnostmi in pomanjkanjem: Maribor v času prvega županskega mandata dr. Alojzija Juvana, 1928-1931.« Acta Histriae 26, št. 1 (2018): 159-80.

- Jenuš, Gregor. »»'Ljubi Bog, kako varovati, česar ni,; saj vendar pri vseh koncih in krajih sili v Mariboru slovenski značaj na dan!': Johann Schmiderer - zadnji mariborski župan avstrijske dobe.« Studia Historica Slovenica 17, št. 3 (2017): 901-28.

- Kranjc, Cene. »Naše tiskarstvo v letih 1918-1938.« V: Spominski zbornik Slovenije: zbornik ob dvajsetletnici Kraljevine Jugoslavije, ur. Jože Lavrič, Josip Mal in France Stele, 226-62. Ljubljana: Jubilej, 1939.

- Maček, Jure. Ukinitveni komisar za društva, organizacije in združenja na Spodnjem Štajerskem. Maribor: Pokrajinski arhiv, 2004.

- Pirjevec, Avgust. Knjižnice in knjižničarsko delo. Celje: Družba Sv. Mohorja, 1940.

- Potočnik, Dragan. Kulturno dogajanje v Mariboru v letih 1918-1941. Maribor: Založba Litera, 2003.

- Potočnik, Dragan. »Literarna ustvarjalnost v Mariboru 1918-1941.« Studia Historica Slovenica 14, št. 2-3 (2014): 417-33.

- Potočnik, Dragan. »Mariborski župan Viktor Grčar (1921-1924).« Studia Historica Slovenica 17, št. 3 (2017): 961-87.

- Potočnik, Dragan. »Vladni komisar Ivan Poljanec (1921).«Studia Historica Slovenica 17, št. 3 (2017): 949.

- Skala, Anton in Vekoslav Špindler. Prosvetno delo 1925-1930: ob petletnici Zveze kulturnih društev v Mariboru. Maribor: Zveza kulturnih društev, 1930.

- Stavbar, Vlasta. Kulturno dogajanje v Mariboru v letih 1914-1918. Maribor: Založba Obzorja, 1998.

- Žnidarič, Marjan. Do pekla in nazaj, Nacistična okupacija in narodnoosvobodilni boj v Mariboru. Maribor: Muzej narodne osvoboditve, 1997.

\section{Dragan Potočnik}

\section{LIBRARIES IN MARIBOR BETWEEN 1918 AND 1941}

\section{SUMMARY}

World War I influenced the life of the Maribor citizens as well, manifesting itself in the increasing national tensions between Slovenians and Germans; restrictions regarding the cultural and social life as well as the life of the societies; and demands that the Yugoslav question be settled.

The socio-political changes after World War I had a decisive impact on Maribor's cultural development. In the new state, the Kingdom of SHS, this city lost its previous economic position and status of a transport hub. The national structure of its population changed.$^{88}$ Libraries are one of the indicators of the cultural developments in Maribor. They spread around the city after 1918.

88 Jerneja Ferlež, »Prebivalstvo Maribora 1848-1991,« Studia Historica Slovenica 2, No. 1 (2002): 79-125. 
In 1921, the pre-war scientific library of the Historical Society for Slovenian Styria transformed into the general scientific Study Library. In 1925, it became a city institution under the auspices of the City of Maribor. Under the expert leadership of Janko Glazer, it soon became the first and largest Slovenian scientific library in Styria. In the interwar period, the libraries in Maribor were - because of the socio-political and ideological splits - divided among three political camps: the liberals with the People's Library; the Catholics with the Educational Catholic Library; and the socialists with the Chamber of Labour Library. Under the leadership of Dr Avgust Reisman, the prewar liberal People's Library developed into an important social life centre in the city. Due to the competition represented by the daily newspapers and magazines as well as the Chamber of Labour Library, it gradually lost its public influence in the 1930s. At the same time, the importance of the Workers' Library was increasing. With its diverse selection of literature and good organisation, it became the best public people's library in Maribor despite the political pressures.

In 1929, the Catholic camp - because of the "competition" represented by the People's Library and the Workers' Library - renewed its Educational Library under the leadership of Franc Sušnik. Meanwhile, the Association of Cultural Societies and its many libraries carried out the mission of promoting the national awakening and Slovenian culture in the territory of the endangered northern national border.

The gradual transformation or people's schools into Slovenian educational institutions also resulted in the creation of Slovenian school libraries, which mostly contained German literature. The library of the Pedagogical Central played an important role as well. With the assistance of the French and British government institutions, the French Club and the Friends of the English Language and Education Society offered French and English literature in their libraries. The German minority in Maribor also had its People's and Children's Library. In 1934, the Slovenian Reading Club, where everyone could read Slovenian and Yugoslav magazines, was established in Maribor. It provided monthly and weekly literary, scientific, entertainment, sports, and other publications as well as women's and family magazines.

The comparison between the libraries reveals that the Study Library had the largest number of books at its disposal as well as the highest borrowing rate. The Chamber of Labour Library had the largest number of members and visitors. More than half of the books checked out in the Study and Educational Library were in Slovenian; while the other two libraries lent a slightly larger number of German books. As the national literary production became more extensive and the number of translations increased, the demand for German books started to decline. This also resulted from the fact that in the 1930s, secondary-school youth was no longer fluent in German. The membership of the Study Library included $60 \%$ of secondary-school and high-school students. Other intellectuals would borrow literature as well. While workers would not often visit this library, the middle class opted for popular literature. Meanwhile, the Educational Library was mostly frequented by the Catholic intellectuals, pupils, as well as the middle class. The membership of the Chamber of Labour Library mainly 
consisted of workers as well as a few intellectuals. Readers would borrow works by Slovenian writers, political and sociological literature, travelogues, and so on. The People's Library was frequented by the middle class as well as by the less demanding readers. World events would influence the borrowing of books as well. Thus, during the Sudeten crisis of 1938, Czech writers were in high demand. Before the onset of World War II, many works by British writers and politicians as well as books by the Nazi writers were read as well.

We can establish that among the inhabitants of Maribor in the period under consideration, books were exceedingly attractive. The Slovenian book production was expanding, publishing flourished, translations into Slovenian multiplied, and the borrowing of Slovenian literature was on the rise. 